\title{
BÓG I RELIGIA JAKO „NOWE TABU”. ATEIZACJA W EDUKACJI
}

Nulla sine Deo mens bona est

Seneka

Obserwując zmiany, jakie dokonują się w dziedzinie ludzkiej kultury - nie możemy nie dostrzegać przemian, jakim ulega edukacja oraz także każda inna dziedzina wychowania człowieka. Zmiany w edukacji zaskakują i to na wiele różnych sposobów. Patrząc na nie, stajemy wobec pytania o to jak je rozumieć, wreszcie jak je wyjaśnić oraz jaki mają one ostatecznie sens i znaczenie dla doskonalenia człowieka. Są to pytania, na które musi udzielić sobie odpowiedzi każdy rozumny i odpowiedzialny pedagog, nauczyciel, rodzice oraz wszyscy twórcy jakichkolwiek form zorganizowanego społecznie systemu edukacji i wychowania - o ile oczywiście autentycznie pragną oni dobra człowieka.

Obok wielu różnych dyscyplin, pomocna w odpowiedzi na te pytania okazuje się być filozofia. Daje ona odpowiedź na pytanie o to, czym jest i dla czego istnieje sama edukacja i wychowanie, ale także pozwala na ukazanie roli edukacji i wychowania w kulturze. Jej owoce poznawcze są i zawsze będą koniecznym i naczelnym czynnikiem w kształtowaniu się rozumienia całej dziedziny edukacji i wychowania.

Filozofia posługując się rozumieniem człowieka (jego natury i potencjalności), dając zasadniczy zrąb rozumienia całej rzeczywistości - pozwala dostrzec i wyjaśnić szereg zagrożeń, które mogą pojawić się w edukacji i wychowaniu ${ }^{1}$. Do takich zaliczyć trzeba w pierwszej kolejności ateizm i laicyzm, w ogóle jakąś formę kształtowania się areligijnej czy antyreligijnej i bezbożnej kultury ludzkiej zamykającej się na Boga. Forma ta ma nie tylko antyludzki charakter, ale jest przyczyną dewastacji edukacji i całej kultury ludzkiej, a przez to zaczynem szkód największych. Ochrona

1 Nie każdy też typ filozofii pozwala na rzeczową analizę tych zagadnień. Jest również prawdą to, że szereg nowożytnych nurtów filozoficznych, będących w swej istocie jedynie krytyką ludzkiego poznania, opowiadających się czy to za relatywizmem poznawczym i moralnym, czy to za jakimiś formami agnostycyzmu, nurtów antymetafizycznych i antyrealistycznych, nie może rzeczowo ani tymi zagadnieniami się zająć, ani też nie dostrzega potrzeby ich podejmowania. Bywają one faktycznie przyczyną ideowego zamieszania, a nierzadko również wprowadzania do edukacji i wychowania samego ateizmu i bezbożnictwa. Zob. H. Romanowski, Aktualność filozofii tomistycznej, Warszawa 1931 (odbitka z „Przeglądu Katolickiego”); M. A. Krąpiec, O rozumienie filozofii, Lublin 1991. 
przed tymi zgubnymi efektami powinna być przedmiotem troski wszystkich zainteresowanych dobrem człowieka realizowanym przez proces edukacji i wychowania. Należy mieć świadomość tego, że jeśli tej rozumnej troski zabranie - dewastacja kulturowa spowodowana przez ateizm i bezbożnictwo w niedalekiej przyszłości otworzą drogę do zjawiska przeciwnego, lecz nie mniej groźnego, jakim jest fundamentalizm religijny, ideologizujący całość ludzkiej kultury.

\section{Potrzeba zrozumienia problemu: podstawowe dystynkcje i supozycje}

Poczynione analizy nie mają na celu jakiejś formy konfesyjnej apologii chrześcijaństwa, choć ochrona, wsparcie i umacnianie tegoż leży w żywotnym interesie całej cywilizacji Zachodu. Znajomość dziejów ukazuje, że zaniechania w tej materii, nieskuteczność i obojętność przynoszą zawsze rozstrój życia indywidualnego, rodzinnego, narodowego i państwowego. Dokonywane analizy są rodzajem filozoficznego namysłu, ukazującego ważny problem pedagogiczny i kulturowy, także narodowy. Zostanie on zaprezentowany na drodze naturalnego, nieodwołującego się do prawd wiary religijnej, dyskursu. Droga ta nie wyklucza jakże potrzebnych dziś działań ludzi religijnych, instytucjonalnych i indywidualnych, dokonywanych w różnych obszarach (prawa, mediów, polityki, szkolnictwa, literatury, sztuki, obronności i innych) zmierzających do obrony, umocnienia i rozwoju szeroko pojętej kultury religijnej, a w sposób szczególny kultury chrześcijańskiej, katolickiej, polskiej ${ }^{2}$.

Bez wątpienia jesteśmy światkami nasilania się procesów przenikania ateistycznych koncepcji i praktyk także do edukacji i wychowania. Pojawia się tu szereg pytań, a wśród nich oto czy edukacja może realizować swe naturalne funkcje i zadania poddana ateizacji i ideologii antyreligijnej? Jakie faktyczne uzasadnienie kryje się za zjawiskiem rugowania Boga i religii z procesu edukacyjnego i wychowawczego człowieka? Oto niektóre problemy, poruszane w niniejszej rozprawie.

W celu należytego przedstawienia zagadnienia ateizacji edukacji trzeba w pierwszej kolejności właściwie dokonać zdefiniowania problemu, aby po jego opisie

\footnotetext{
2 Przywołać tu można wnioski, jakie zaprezentował przed laty F. Koneczny, który jasno przy wykorzystaniu wiedzy historycznej, wykazywał, że upadek katolicyzmu jest w Polsce ruiną polskości, narodu i ostatecznie także państwa, oraz także w dalszej perspektywie - cywilizacji Zachodu, cywilizacji łacińskiej. Koneczny pisał: „Kto ocali u nas cywilizację łacińską? Jedną tylko znam siłę, do tego zdatną i powołaną: Kościół. Tu, w Europie w ogóle, jest to jego cywilizacja, jego córa, bronić mu przeto wypadnie swej własności, swego żywiołu. Ale powodzenie zależy od tego, czy miłośnicy tej cywilizacji zrozumieją, że nie obronią jej, jeśli nie staną zarazem w szeregach Kościoła. W tej walce trzeba być koniecznie katolikiem, inaczej walka będzie próżną. Można by nawet wyrazić się, że wystarcza walczyć o katolickość Polski, a gdy obronimy Kościół ... cywilizacja łacińska będzie nam przydana, ocalona", F. Koneczny, Napór Orientu na Zachód, w: Kultura i cywilizacja, praca zbior., Lublin 1937, s. 195-196.
} 
i interpretacji dać wyjaśnienie jego natury oraz zaprezentować racje istnienia samego zjawiska danego do wyjaśnienia. Nie jest to zadanie łatwe ${ }^{3}$. Uczynić to można przede wszystkim na gruncie poznania i rozumienia o charakterze filozoficznym. Dopiero po wykonaniu tego, można należycie zrozumieć konsekwencje i charakter edukacji, w której doszło do jej złączenia $\mathrm{z}$ ateizmem, laicyzacją, agnostycyzmem, subiektywizmem czy też bezbożnictwem. Ale czym jest edukacja i jak pojąć wychowanie? Czym jest ateizm i co ateizmem nie jest? Czym jest wreszcie ludzka kultura i obecny w niej system wychowania i edukacji?

\section{1. Edukacja i wychowanie w kulturze ludzkiej}

Kultura jest w swej istocie uprawą człowieka, jest procesem doskonalenia go w tym, co istotnie ludzkie, aby dzięki temu człowiek mógł osiągnąć właściwy dla siebie cel, ku któremu całym swym istnieniem się wyrywa i skłania ${ }^{4}$. Sens istnienia kultury kryje się w doskonałości człowieka, ta zaś jest przez niego osiągana dzięki aktualizacji jego osobowych potencjalności ${ }^{5}$. Dlatego też sens istnienia wszelkich dyscyplin, nauk i sztuk, a także edukacji, która jest celowym i skutecznym procesem zdobywania przez człowieka prawdy, zawiera się w pełnej doskonałości człowieka i nie jest mierzony czymś, lecz kimś, tj. osobą ludzką i jej dobrem6.

Edukacja w najbardziej podstawowym sensie jest formą rozwoju intelektualnego człowieka, formą zorganizowaną i celową, której sens kryje się w poznaniu i zrozumieniu prawdy o świecie, jak i samym człowieku. Przychodząc na świat,

3 Zob. Filozofia i edukacja, red. P. Jaroszyński, P. Tarasiewicz, I. Chłodna, Lublin 2005.

4 Zob. M. A. Krąpiec, Kultura, w: Powszechna Encyklopedia Filozofii, t. 6, red. A. Maryniarczyk, Lublin 2005, s. 132-133.

5 Jasno to wyrażało wielu filozofów związanych z cywilizacją Zachodu, lecz chyba najpełniej oddał to św. Tomasz z Akwinu słowami: „Omnes autem scientiae et artes ordinantur in unum, scilicet ad hominis perfectionem, quae est eius beatitudo.”, Św. Tomasz z Akwinu, Komentarz do „Metafizyki” Arystotelesa, prooemium.

6 Można pokusić się o tezę, że jedną z przyczyn ateizacji kultury, jak i samej edukacji i wychowania, było odchodzenie w dziejach od dotychczasowego pojmowania kultury na rzecz jej ujęcia jako dziedziny wykreowanych i pochodnych tylko od człowieka wartości. Jak pamiętamy, takie rozumienie kultury stało się możliwe dzięki subiektywistycznej i agnostycznej filozofii I. Kanta, który nie tylko „udowadniał” niemożność poznania istnienia Boga, jego natury i relacji świata wraz z człowiekiem do Boga, ale także istoty samej religii, która w tym ideowym kontekście staje się jakąś formą subiektywnego i pozbawionego realnych podstaw przeżycia emocjonalnego. Sam Kant, świadom ograniczeń swojego systemu, ostatecznie skłonił się ku przekonaniu, że kultura moralna, wraz z wychowaniem, powinna opierać się na postulacie istnienia Boga jako gwaranta powszechnej sprawiedliwości oraz na postulacie nieśmiertelności ludzkiej duszy, lecz jednocześnie był on świadom, że są to tylko ludzkie postulaty, a zatem coś, co wymyka się wartościowemu i racjonalnemu dyskursowi. Skoro tak, to nie może być o nich nauki, nie mogą się stać one elementem nauczania. Stają się one raczej domeną wiary i religijnych przeżyć, które są poza możliwościami racjonalnej analizy. Zob. M. A. Krąpiec, U podstaw rozumienia kultury, Lublin 1991. 
człowiek nie posiada prawdy i dopiero w wyniku żmudnego i długotrwałego działania jest w stanie, często dzięki pomocy innych, choć niedoskonale i z domieszką błędów, prawdę posiąść, zrozumieć i dzięki temu uwolnić w sobie swój rozum, swe racjonalne życie. Intelekt ludzki bez prawdy - nie jest sobą, nie ma mocy prowadzenia człowieka do dobra, a z racji tego, że wolność ludzka korzeniami tkwi w rozumie - bez prawdy obecnej w intelekcie nie ma również wolności, lecz jedynie swawola, ślepa i katastrofalna w swych skutkach samorzutność bytu ludzkiego ${ }^{7}$. Edukacja to aktualizacja ludzkich potencjalności intelektualnych na drodze poznania, przez związanie ludzkiego rozumu prawdą i jej rozumieniem.

Edukacja dzięki prawdzie może stać się środkiem budującym wolność. Z tej racji słusznie zwraca się uwagę na to, że edukacja to droga, to proces wyprowadzenia człowieka do poznania przez niego prawdy, to podróż do rozumnego życia w prawdzie i samo życie duchowe trwające dzięki poznawaniu prawdy ${ }^{8}$.

Tak pojęty proces w naturalnym ludzkim życiu splata się z wychowaniem, czyli doskonaleniem człowieka do samodzielnej, skutecznej i odpowiedzialnej realizacji dobra godziwego. Wychowanie na gruncie cywilizacji Zachodu zawsze dokonywało się za sprawą pozyskania przez człowieka cnót i wyzbycia się wad ${ }^{9}$. Cnoty jako trwałe dyspozycje do dobra umożliwiały człowiekowi bycie dobrym, jak i dobre działanie, były pożytkiem tak dla tego, kto je posiadł, jak i całej społeczności ludzkiej, w której żył i działał człowiek ${ }^{10}$.

Zarówno wychowanie, jak i edukacja posiadają swe społeczne osadzenia w naturalnych kręgach ludzkiego życia, takich jak: rodzina, społeczność lokalna (gmina), społeczność narodowa i państwowa. Bez współdziałania tychże kręgów, bez ich

\footnotetext{
7 Kultura Zachodu jest kulturą rozumnej wolności do dobra, wolności w prawdzie - radix totius libertatis est in ratione posita; zob. STh I-II, q. 83. Wolność bez prawdy nie istnieje, zaś wszelki wolny ludzki wybór oraz jego wykonanie ma sens i zasługuje na afirmację jeśli związany jest $\mathrm{z}$ dobrem prawdziwym, dobrem godziwym. Edukacja z racji zaznajamiania człowieka z prawdą jest też etapem ludzkiego życia związanym z budowaniem w sobie wolności, stąd od czasów Marcjana Kappelli, Kajsodora mamy artes liberales (sztuki wyzwolone, nauki wolne; sztuki dla ludzi wolnych; sztuki prowadzące do wolności ludzkiej, zob. T. Borawska, K. Górski, Umysłowość średniowiecza, Warszawa 1993, s. 29-31.

$8 \quad$ Z perspektywy filozoficznej można nazwać proces edukacji interioryzacją inteligibilności świata osób i rzeczy. Proces ten zakłada i wymaga istnienia prawdy w świecie, zdolności poznawczych człowieka oraz szeregu innych czynników. Z góry wyklucza on takie stanowiska, jak subiektywizm, relatywizm, agnostycyzm, jako przejawy i formy myślenia ludzkiego, utrudniając dojście do prawdy i życie w prawdzie. Edukacja bez prawdy zamienia się w działanie ideologiczne, szkodzące człowiekowi, sprzeczne z jego godnością, wolnością oraz prawem do rozwijania swej rozumności; zob. P. Skrzydlewski, Prawo człowieka do edukacji, w: Filozofia i edukacja. Materiały z sympozjum z cyklu „Przyszłość cywilizacji Zachodu” zorganizowanego przez Katedrę Filozofii Kultury KUL, red. P. Jaroszyński, P. Tarasiewicz, I. Chłodna, Lublin 2005, s. 129-149.

9 Zob. Z Pańpuch, Aretologia, w: Powszechna encyklopedia filozofii, t. 1, red. A. Maryniarczyk, Lublin 2000, s. 325-329.

10 Zob. W. Jaeger, Paideia. Formowanie się człowieka greckiego, Warszawa 2001; H. I. Marrou, Historia wychowania w starożytności, Warszawa 1969.
} 
wzajemnej ku sobie życzliwości oraz pracy, człowiek nie stanie się ani mądry, ani dobry. Kręgi te wymagają różnorodnych środków, mają swe specyficzne zadania, ale przede wszystkim potrzebują afirmacji ze strony samego człowieka oraz teorii, która całościowo ujmuje zagadnienie wychowania i edukacji ${ }^{11}$. Teoria ta umożliwia pedagogię i jest ona w swej zasadniczej części dziełem filozoficznego rozumienia świata i człowieka. Nie można jej dowolnie zmieniać, jej siła oddziaływania płynie głównie przez utrwaloną tradycję oraz wzorce edukacyjne i wychowawcze, z którymi styka się człowiek głównie w swej rodzinie oraz w życiu narodowym. Z tej racji zinstytucjonalizowane formy edukacji i wychowania (przedszkole, szkoła podstawowa, gimnazjum, liceum) - obecne czy to w rzeczywistości lokalnej (gminnej), czy to państwowej (uniwersytet, politechnika, akademia) stoją przed zadaniem poszanowania i pielęgnowania tradycji oraz współpracy z rodziną i narodem, tak aby mogło spełniać się autentycznie dobro człowieka. Gdy będzie brak tej współpracy, wszelkie działania muszą okazać się nie tylko bezowocne, ale i szkodliwe ${ }^{12}$.

$Z$ racji tego, że człowiek jest istotą rozumną, a rozum ludzki jest uwalniany i doskonalony przez prawdę (rozumienie świata osób i rzeczy), w wychowaniu zawsze musiała towarzyszyć edukacja, która pozwala rozumieć samo dobro, ale także poznać prawdę o tym, jakim dobrem jest dane, konkretne dobro (motyw i cel działania ludzkiego). Edukacja umożliwiała rozpoznanie i ocenę środków do tego dobra, godziwie i skutecznie prowadząc człowieka do jego osiągnięcia. Było to zadanie etyki, w świetle której kształtowała się kultura moralna osoby. Bez poznania autentycznego dobra nie jest możliwa jego prawdziwa miłość (ignoti nulla cupido; nihil volitum nisi praecognitum) oraz wychowanie człowieka do dobrego działania i dobrego życia. Prawda zdobywana w edukacji dawała także człowiekowi szansę na zrozumienie w ogóle sensowności wszelkich ludzkich poczynań oraz ukazanie celu ostatecznego, który stoi za wszelkimi poczynaniami człowieka. Cel ów, jeden

11 Zob. J. Woroniecki, Katolicka etyka wychowawcza, t. 1-2, Lublin 1986.

12 W dziejach Polski dowodem na to jest choćby los reformy edukacyjnej Komisji Edukacji Narodowej, która „wydała ustawy oparte na zasadach bardzo liberalnych. Dla wszystkich klas narodu otworzono po całym kraju akademie, gimnazja i szkoły; wszędzie każdy mógł uczęszczać bez żadnej opłaty, młodzieży uczącej się nadano wszelkie przywileje, starano się wszelkimi sposobami ją zachęcić. Ale cała ta popiętrowana budowa oświaty czyli instytucji publicznej nie miała podstawy w żadnej prawdzie moralnej, w żadnym dogmacie ogólnym. Nasprowadzano z zagranicy dzieł, które miały służyć za elementarne, książki te pisane przez filozofów, Encyklopedystów, znajdowały się w dużej sprzeczności z wychowaniem religijnym, zostawionym jeszcze w ręku duchowieństwa. Logika, umiejętności ścisłe i wszystko czego uczono w szkołach było już wykładane podług widoków materializmu. Podrzędne zbiory historii, wyciągane z dzieł cudzoziemskich republikanów, wpajały maksymy tchnące nienawiścią przeciwko monarchii, a obok tego starano się wystawić uczniom dziedziczną władzę królewską jako jedyny środek zbawienia rzeczpospolitej. Tym sposobem przez 20 lat edukowano młodzież, która z głową zawróconą tłumem pomieszanych pojęć, miała wyszedłszy na świat objąć rząd kraju i zreorganizować Polskę. Z tej to młodzieży składała się później większość Sejmu Czteroletniego, zwanego Wielkim” A. Mickiewicz, Literatura słowiańska, Poznań 1865, t. II, s. 169. 
dla wszystkich ludzi, miał swe poznawcze wsparcie również przez edukację religijną, odwołującą się do treści objawionych, przyjmowanych na mocy aktu wiary religijnej. Stąd edukacja ludzka była nierozerwalnie związana z edukacją religijną i kulturą religijną.

Edukacja zmierzała zatem do ukształtowania w człowieku światopoglądu, lub też mówiąc inaczej mądrości, pozwalającej dobrze i rozumnie żyć, oceniać, działać, wytwarzać. Bez tego właśnie elementu, bez ugruntowania go w dobru człowieka, edukacja częstokroć staje się tylko procesem zdobywania informacji, procesem socjalizacyjnym, który przystosowuje człowieka, lecz nie czyni go ani suwerenem, ani faktycznym podmiotem. Bez dojrzałej mądrości ludzkiej - jako celu właściwego - edukacja co najwyżej może być elementem procesu ideologizacji i indoktrynacji człowieka.

Dzieje kultury Zachodu wykazały, że nie można utożsamić wychowania i edukacji, że naturalny porządek ludzkiego życia wymaga podporządkowania procesu edukacyjnego dobru człowieka oraz wymogom wychowania, gdyż wiedza i poznanie nie czyni człowieka dobrym niejako automatycznie; sam zaś rozwój intelektualny człowieka może prowadzić do uzbrojenia go do czynienia zła.

Toteż tradycja cywilizacyjna Zachodu stawia przed człowiekiem w pierwszej kolejności nakaz: czyń dobro, unikaj zła i w świetle tej zasady ocenia wszystko, również system edukacyjny, który uwolniony od władztwa dobra godziwego zawsze stanie się środkiem indoktrynacji, manipulacji i zepsucia człowieka ${ }^{13}$. Innymi słowy uświadomiono sobie błąd intelektualizmu moralnego i jego zgubnych konsekwencji; zrozumiano, że nie ma dobrego życia bez gruntownej znajomości prawdy oraz prawdziwie ludzkiego życia bez dobrowolnej i rozumnej miłości tego, co dobre, godziwe i zarazem prawdziwe ${ }^{14}$.

Autentyczna kultura Zachodu kształtuje zatem osobę ludzką do dobrowolnych i rozumnych decyzji, do odpowiedzialnego życia indywidualnego i rodzinnego, narodowego - nie zaś do ślepego posłuszeństwa prawu, tradycji, uległości wobec autorytetów i władzy, które są pozbawione moralnego ugruntowania w dobru godziwym. Wychowany i wykształcony człowiek umie i potrafi władać sobą, nie jest zaś kierowany i rządzony, raczej kieruje się sam rozumnie ku dobru ${ }^{15}$. Jest on suwerenem, a jego rozumna wolność złączona z odpowiedzialnością ani nikomu nie szkodzi, ani też przeszkadza w wolności i rozumności innych. Cały ten ład i paradygmat edukacyjno-wychowawczy ostatecznie zasadza się na afirmacji ludzkiej godności, podmiotowości, na prymacie osoby w stosunku do całego zrzeszenia, jaki i środków, które w sposób temu właściwy towarzyszą życiu ludzkiemu.

13 Zob. H. Kiereś, Zagłada - przemoc-manipulacja, w: tenże, Służyć kulturze, Lublin 1998, s. 37-44.

14 Zob. P. Jaroszyński, Kalokagathia, „Człowiek w Kulturze” 2 (1994), s. 31-42.

15 Ten właśnie aspekt dobrego wykształcenia i wychowania w kulturze Zachodu interesująco opisał i wyjaśnił na kanwie etyki klasycznej J. Woroniecki w szeregu swoich publikacji, zob. tenże, Umiejętność rządzenia i rozkazywania, Poznań 1947. 
Zdano sobie również sprawę z tego, że łączenie wychowania i edukacji jest nie tylko działaniem trudnym, ale także narażonym na różne błędy, które ostatecznie skutkują nieszczęściem i jakimś kalectwem, brzydotą człowieka, ludzkiej społeczności. Z czasem okazało się jasne, że w wychowaniu i edukacji uczestniczy człowiek - podmiot, suweren, który nie tyle ma zostać zideologizowany i wytresowany, co udoskonalony do dobrowolnej i rozumnej formy życia, która jednocześnie służąc jemu samemu, służy innym, a także sprzyja osiągnięciu przez wszystkich celu ludzkiego życia ${ }^{16}$.

Zadanie to jest bardzo trudne do osiągnięcia $\mathrm{z}$ wielu powodów, lecz przede wszystkim z faktu konieczności wolnego i rozumnego zaangażowania się w nie samego człowieka. Człowiek powinien chcieć tego, co dobre, umieć to, co dobre zrealizować, jednocześnie będąc życzliwym i pomocnym dla innych. Edukacja i wychowanie w tym kontekście to konieczne sposoby doskonalenia człowieka, spełniane w społeczności ludzi. Ich realizacja umożliwia szereg innych dóbr człowieka, faktycznie sprawia, że rzeczywistość kulturowa i społeczna ma autentycznie ludzki charakter. Świadectwem tego charakteru jest wszechobecność przyjaźni, tej odwzajemnionej życzliwości i miłości złączonej z radosnym współżyciem, obcowaniem jednych $z$ drugimi.

Celem ostatecznym życia ludzkiego, jak wykazały to filozoficzne analizy (także będąca udziałem człowieka religia) - jest Bóg ${ }^{17}$. Z tej racji edukacja, wychowanie (cała dziedzina ludzkiej kultury) w sposób zreflektowany, czy też nie, jest odniesiona do Boga, celu i sensu ludzkiej egzystencji ${ }^{18}$. Jeśli takowy Cel swój ignoruje, jeśli Go zwalcza lub też rozmyślnie o Nim próbuje zapomnieć, lekceważyć Go, lub też zaczyna deformować prawdę o Nim - nie tylko zasługuje na miano kultury bezsensownej, ale także kultury antyludzkiej, kultury zbrodniczej, upadlającej człowieka. Człowiek może bowiem źle żyć, może być złym, może być głupim, a przez to przyczyną swego i innych osób nieszczęścia. Bez edukacji i wychowania

16 Zob. M. A. Krąpiec, Filozofia moralności, w: Powszechna encyklopedia filozofii, t. 3, red. A. Maryniarczyk, Lublin 2002, s. 494-499.

17 Zob. A. Gmurowski, Doskonałość chrześcijańska w myśl zasad św. Tomasza z Akwinu. (Studium teologiczne), Gniezno 1934.

18 "Respondeo dicendum quod impossibile est beatitudinem hominis esse in aliquo bono creato. Beatitudo enim est bonum perfectum, quod totaliter quietat appetitum, alioquin non esset ultimus finis, si adhuc restaret aliquid appetendum. Obiectum autem voluntatis, quae est appetitus humanus, est universale bonum; sicut obiectum intellectus est universale verum. Ex quo patet quod nihil potest quietare voluntatem hominis, nisi bonum universale. Quod non invenitur in aliquo creato, sed solum in Deo, quia omnis creatura habet bonitatem participatam. Unde solus Deus voluntatem hominis implere potest; secundum quod dicitur in Psalmo C II, qui replet in bonis desiderium tuum. In solo igitur Deo beatitudo hominis consistit", STh I-II, q. 2, art. 8, resp. 
będzie głupi, zły i nieszczęśliwy, a zatem edukacja oraz wychowanie są dla niego koniecznością nie mniej pilną jak odżywianie i sen ${ }^{19}$.

Trzeba tu także podkreślić, że z czasem uświadomiono sobie prawdę o tym, że cel ludzkiego życia, tj. Bóg, jest osiągany dobrowolnie oraz dzięki wsparciu natury ludzkiej przez nadprzyrodzone pomoce (Łaskę Boga), bez której osiągnięcie ostatecznego celu - Boga, Bytu Nadprzyrodzonego, nie jest możliwe. Żadne środki naturalne nie mają mocy doprowadzenia człowieka do tego, Kto Jest Bytem Nadprzyrodzonym, transcendującym całkowicie świat ${ }^{20}$. $\mathrm{Z}$ tej też racji cała kultura ludzka oraz obecne $w$ nich edukacja i wychowanie są z uwagi na ostateczny cel ludzkiego życia - otwartymi na dopełnienie i uszlachetnienie przez środki nadprzyrodzone (łaska Boga) ${ }^{21}$.

Innymi słowy w cywilizacji łacińskiej dostrzegano oraz szanowano wychowawcze i edukacyjne walory religii i życia religijnego, przez które dociera do człowieka łaska Boga, umożliwiająca spełnienie się ostateczne natury ludzkiej. Edukacja i wychowanie rugujące Łaskę, deprecjonujące religię, pojętą jako osobowa i dobrowolna więź człowieka z Bogiem, nie tylko jawiła się zawsze jako rzeczywistość zdefektowana, ale także bardzo często zagrażająca samemu człowiekowi z racji nigdy nie wygasłych w naturze ludzkiej inklinacji do instrumentalizowania drugich ludzi, do czynienia sobie z nich środka do dowolnego użycia. Walka systemów totalitarnych, jaką w dziejach obserwowaliśmy i dostrzegamy także i dziś, o usunięcie

19 „Zapytany [Arystoteles], czym różnią się ludzie wykształceni od niewykształconych, odpowiedział: Tym, czym żywi i umarli. Mawiał, że wykształcenie jest $w$ chwilach pomyślności ozdoba, a w chwilach nieszczęścia - schronieniem. Rodziców, którzy kształcili swe dzieci, uważał za godnych szacunku od tych, którzy je tylko spłodzili, bo ci drudzy dali im tylko życie, a ci pierwsi - piękne życie”, (Diagones Laertios, Żywoty i poglądy słynnych filozofów, Warszawa 1982, s. 264.

$20 \mathrm{~W}$ tej kwestii jasno wypowiada się św. Tomasz z Akwinu, zaznaczając, że „Gdyby cel ten można było osiągnąć mocą ludzkiej natury, prowadzenie do niego stanowiłoby obowiązek króla. Zakładamy bowiem, że tego nazywamy królem, komu powierzono najwyższe rządy w sprawach ludzkich. Otóż władza jest tym wyższa, im do dalszego celu prowadzi. I zawsze jest ktoś, do kogo należy wydawanie rozkazów, aby to, czego się dokonuje, było zwrócone do celu ostatecznego. W ten sposób sternik, który czuwa nad żeglowaniem, rozkazuje budowniczemu okrętu, jaki okręt powinien zbudować, aby się nadawał do użytku; obywatel zobowiązany do używania broni rozkazuje rusznikarzowi, jaką broń powinien sporządzić. Ponieważ jednak celu, jakim jest nasycanie się Bogiem, nie osiągnie człowiek mocą ludzką, lecz Bożą, prowadzenie do tego celu ostatecznego nie jest zadaniem rządów ludzkich, lecz Bożych; jak powiada Apostoł: »Łaską Bożą jest życie wieczne« (Rz 6, 23)”; O władzy, w: tenże, Dzieła wybrane, Poznań 1994, s. 152).

21 Problem ten jasno ukazuje św. Tomasz z Akwinu pisząc, że „(...) nie ma wątpliwości, że wszystko co ziemskie, jest niższe od ludzkiego umysłu. Szczęście zaś stanowi ostateczną doskonałość i całkowite dobro człowieka, które wszyscy pragną osiągnąć. Nic więc, co ziemskie, nie może człowieka uczynić szczęśliwym (...) nic też innego, co stworzone, nie może uczynić człowieka szczęśliwym i zostać wyznaczonym (...) za nagrodę. Albowiem pragnienie każdej rzeczy zwraca się ku swojemu początkowi, który jest przyczyną istnienia. Otóż przyczyną ludzkiego umysłu jest nie co innego, tylko Bóg, który uczynił go na swój obraz. Zatem jeden tylko Bóg może zaspokoić pragnienie człowieka i uczynić go szczęśliwym", O władzy, w: tenże, Dzieła wybrane, Poznań 1994, s. 145. 
religii z kultury, ich praktyka edukacyjna i wychowawcza w oparciu o jakąś postać ideologii (komunistycznej, bolszewickiej, rasistowskiej, syjonistycznej, liberalnej, socjalistycznej, ekonomizmu itp.) są najlepszym tu dowodem na zgubne skutki dla edukacji i wychowania areligijnego czy też antyreligijnego ${ }^{22}$.

Nie oznacza to jednak, że wychowanie i edukacja mają swój jedyny fundament w religii i w sprawach z nią związanych, a kultura ludzka ma zostać poddana arbitralnej formie sakralizacji. Wręcz przeciwnie oznacza to, że przed każdym działem kultury leży potrzeba realizacji właściwych celów i posługiwania się właściwymi środkami w świetle odczytanej przez człowieka prawdy o jego własnej naturze, zawartych w niej reguł i praw ${ }^{23}$. Łaska płynąca ze strony Boga uszlachetnia i uświęca naturę, nie zaś znosi jej porządek - oto proprium znane cywilizacji łacińskiej od czasów św. Augustyna.

Jeśli zatem chodzi o naukę i dziedzinę poznania, celem jest tu prawda i jej uzyskanie w postaci wiedzy, rozumienia. Jeśli zaś mamy na uwadze życie moralne człowieka, dziedzinę etyki, rzecz w tym, by uformować człowieka do dobrego działania i życia. Jeśli kierujemy swą uwagę w stronę sztuki wraz z techniką - celem staje się tu piękno lub użyteczność, związana z zaistnieniem i wykorzystaniem środków do życia.

Całość zatem ludzkiej kultury (nauka, etyka i sztuka) mają swe dopełnienie, nie zaś zastąpienie w religii i życiu religijnym człowieka, które ze swej istoty jest przyporządkowane ludzkiej świętości, zbawieniu człowieka i życiu doskonałemu w wiecznym szczęściu, co jest możliwe za sprawą zjednoczenia człowieka z Bogiem, osiąganego przez dobre życie i doskonalącą moc łaski Boga.

Rozumienie tych zagadnień jest konieczne. Na ich gruncie dopiero można dostrzec czym jest faktycznie ateizm i postulat ateizacji edukacji i wychowania, który w praktyce jest zazwyczaj pewną formą szerzenia bezbożności lub jakiejś postaci pogaństwa przez ośrodki szkolne i wychowawcze.

\subsection{Konieczność wykształcenia filozoficznego}

Przy analizie skutków ateizacji edukacji szczególne znaczenie wydaje się posiadać filozofia realistyczna i metafizyczna, zmierzająca do sapiencjalnego i ostatecznościowego ujęcia całej rzeczywistości, w tym rzeczywistości samego człowieka oraz

22 Zob. B. Jasinowski, O cywilizacji wschodnio-chrześcijańskiej, w: Kultura i cywilizacja, praca zbior., Lublin 1937, s. 150-175; tenże, Wschodnie chrześcijaństwo a Rosja na tle rozbioru pierwiastków cywilizacyjnych Wschodu i Zachodu, Wilno 1933.

${ }_{23}$ Zob. P. Jaroszyński, Filozofia kultury, w: Powszechna encyklopedia filozofii, t. 3, red. A. Maryniarczyk, Lublin 2002, s. 478-480. 
jego kultury ${ }^{24}$. Jej posługa wydaje się być szczególnie potrzebna zwłaszcza dziś, gdy we współczesnej refleksji nad edukacją i wychowaniem daje się zauważyć nasilenie teoretycznych ujęć, które bądź to problem ateizacji i antyreligijności edukacji i wychowania bagatelizują, bądź w ogóle nie dostrzegają w tym jakiegoś istotnego zagrożenia dla człowieka. Dochodzą tu współcześnie pewne koncepcje, które wprost kreują ateistyczną, antyreligijną formę edukacji i kultury, widząc w tym nie tylko „zbawienny” dla człowieka zabieg, ale i też nieunikniony kres, ku któremu ma zmierzać świat ze swymi kulturowymi i cywilizacyjnymi przemianami ${ }^{25}$.

Realistyczna filozofia metafizyczna jest potrzebna również i z racji konieczności obrony ludzkiej kultury przed religijnymi i cywilizacyjnymi fundamentalizmami, które sakralizując całą ludzką rzeczywistość, a w sposób szczególny starają się zadbać o sakralną ideologizację edukacji i wychowania. Instrumentalizując samą religię, a nawet czyniąc próby „używania” Boga do swych celów, fundamentalizmy te nie tylko szkodzą edukacji i wychowaniu, ale także samemu życiu duchowemu i religijnemu, które częstokroć pogrąża się w odmętach fanatycznego irracjonalizmu, nietolerancji, woluntaryzmu. Są one „trucizną” dla ludzkiego rozumu, w miejsce jego prawości dają zacietrzewienie i ślepotę na prawdę, w miejsce gorliwości i ofiarności - fanatyzm i zbrodnie. Pojawia się w nich forma kształcenia, która „ma tylko jedną religijną prawdę i wierzeniowe ugruntowanie” oraz sposób kształtowania życia moralnego, który czerpie swe uzasadnienie tylko z sakralnego, religijnego prawa ${ }^{26}$. Ich efektem jest niedorozwój człowieka w dziedzinie intelektualnej i moralnej, często pojawienie się działań kulturowych, które stoją w rozbieżności z prawami osoby ludzkiej. Przykładem tego jest choćby znana w Oriencie kastowa forma życia ludzkiego, czy też deprecjacja uprawnień człowieka, która płynie z jego płciowości, wieku lub uposażenia majątkowego ${ }^{27}$.

${ }^{24}$ Zob. M. A. Krąpiec, Specyfika realistycznej metafizyki, w: Metafizyka w filozofii, red. A. Maryniarczyk, K. Stępień, Lublin 2004, s. 17-36.

${ }^{25}$ Przykładem tego jest nurt filozoficzny związany z indywidualizmem i z apoteozą człowieka i jego wolności, jaki odnajdziemy np. u F. Nietzschego. Co interesujące, wraz z głoszoną przez tego niemieckiego myśliciela śmiercią Boga (idei Boga w ludzkiej kulturze) szła nienawiść do człowieka dotkniętego słabością czy też niedoskonałością. Sam Nietzsche: „Co jest dobre? - Wszystko, co miał pisać: „uczucie mocy, wolę mocy, moc samą w człowieku podnosi. Co jest złe? - Wszystko, co z słabości pochodzi. Co jest szczęściem? - Uczucie, że moc rośnie - że przezwycięża się opór. Nie zadowolenie, jeno więcej mocy; nie pokój w ogóle, jeno wojna; nie cnota, jeno dzielność [...]. Słabi i nieudani niech sczezną: pierwsza zasada miłości dla ludzi. I pomóc należy im jeszcze do tego. Co jest szkodliwsze, niż jakikolwiek występek? - Litość czynna dla wszystkiego, co nieudane i słabe chrześcijaństwo [...]”, F. Nietzsche, Antychryst, Warszawa 1907, s. 6.

${ }^{26}$ Zagadnienia te w literaturze polskiej jasno opisywał i wyjaśnią Feliks Koneczny, zob. tenże Obronić cywilizację łacińską!, Lublin 2002 - zob. także tenże, Rozwój moralności, Lublin 1938.

27 Szeroko o tych zagadnieniach pisał M. A. Krąpiec, zob. tenże Prawa człowieka i ich zagrożenia, „Człowiek w Kulturze” 3 (1994), s. 5-109; tenże Ludzka wolność i jej granice, Lublin 2004 - całość; tenże Człowiek i prawo naturalne, Lublin 2009; zob. także P. Skrzydlewski, Cywilizacyjne determinanty 
Nawet dla niewprawnego obserwatora jest rzeczą jasną, że zarówno ateizacja (bezbożnictwo), jak i sakralizacja edukacji, musi odbijać się pejoratywnie na dobru człowieka, nieść zgubne konsekwencje dla całej kultury, która przecież koniecznie potrzebuje do swego istnienia wykształconego człowieka, który jest jednocześnie dobrym człowiekiem. Czy zatem religia i wreszcie sam Bóg, jego rozumienie i obecność stają się na naszych oczach swoistym „nowym tabu”, o którym raczej nie należy mówić?

Filozofia pozwala także zrozumieć, że realizacja edukacji ateistycznej, bezbożnictwa i milczenie o Bogu w szkole, uniwersytecie jest także zagrożeniem z powodu tego, czym faktycznie jest religia w życiu człowieka ${ }^{28}$. Jeśli bowiem Bóg jest racją istnienia wszystkiego, ale i także celem życia ludzkiego, Kimś Kto człowieka ponad wszelkie niedostatki miłuje, uwalniając od zła wszelkiego daje życie wieczne, to nieobecność Boga w ludzkim życiu jest brakiem najpoważniejszym, podobnie jak nieznajomość Boga jest niewiedzą najgorszą. Jest także największą niesprawiedliwością.

Istnieje zatem potrzeba przypominania i obrony klasycznych rozwiązań leżących u podstaw cywilizacji Zachodu w dziedzinie edukacji i wychowania. Rozwiązania te ani nie dokonywały sakralizacji ludzkiej paidei - ani też w żadnej mierze nie pozwalały na jej dewastację przez ateizm, laicyzm i bezbożnictwo. Idąc za wskazaniami św. Augustyna i św. Anzelma z Cantenbury, Akwinaty oraz związanej $\mathrm{z}$ nimi tradycji, edukacja i wychowanie były budowane w oparciu o zasady: credo ut intelligam, intelligo ut credam.

Dla współczesnego człowieka rozumienie jednak tych zagadnień nie jest proste, ani też łatwe $z$ racji nakładających się na te zagadnienia aprioryzmów, uprzedzeń czy też jawnych błędów poznawczych, ideologii. Fatalne skutki przynosi tu przede wszystkim bardzo mizerna i powierzchowna edukacja filozoficzna. Warto tu podkreślić powszechny błąd, niezwykle ugruntowany w świadomości współczesnych, jakim jest przekonanie, że istnienie Boga to przede wszystkim i jedynie przedmiot wiary religijnej i jako taki może być rozpatrywany jedynie gdzieś na polu teologii, nie zaś na płaszczyźnie poznania autonomicznego w stosunku do wiary religijnej. Wiara religijna zaś bywa tu ujmowana nie jako akt rozumu i woli człowieka, zrodzony ze wsparcia łaską Boga, związany z asercją i afirmacją objawionej Prawdy, ale jest postrzegany jako ślepe i irracjonalne przeżycie, pozbawione rzeczowego uzasadnienia i wyjaśnienia ${ }^{29}$. Ma ono w tym ujęciu naturę emocjonalną, niera-

prawa stanowionego w kontekście totalitaryzmów, w: Totalitaryzm - jawny czy ukryty?, red. P. Jaroszyński i in., Lublin 2010, s. 151-182.

28 Zob. Z. J. Zdybicka, Religia, w: Powszechna encyklopedia filozofii, t.8, red. A. Maryniarczyk, Lublin 2007, s. 720-732.

29 Credere est actus intellectus assentientis veritati divinae ex imperio voluntatis a Deo motae per gratiam, św. Tomasz z Akwinu, Sth, II-II, q. 2, 9. Warto tu podkreślić, że akt wiary religijnej ma za przedmiot Prawdę i nie jest jedynie jakimś przeżyciem emocjonalnym człowieka, choć uczuć nie wyklucza; stąd w cywilizacji Zachodu zwykło się definiować akt wiary religijnej jako akt człowieka 
cjonalną. Tymczasem wiara nie nakazuje uznawać że Bóg jest, lecz że jest jeden, że jest np. sędzią sprawiedliwym, który za dobro wynagradza, zaś za zło karze.

Istnienie Boga to problem naturalnego ludzkiego poznania, uniesprzeczniającego fakt bytowania przygodnego świata, który właśnie z racji swej przygodności domaga się racji dostatecznej, tego, że jest i czym jest. Zagadnień tych nie rozumie współczesny człowiek, pozbawiony znajomości metafizyki, ogołocony ze znajomości elementarnej logiki i metodologii. Jest mu niezwykle trudno pojąć, że rozum ludzki poznający zmienny i niekonieczny świat jest w swym wyjaśnianiu świata prowadzony do przyjęcia tezy o konieczności istnienia Boga. Jakże może ona okazać się pomocną dla otwarcia się i przyjęcia przez niego religijnej wiary.

Samo jednak uznanie istnienia Boga nie czyni człowieka religijnym, gdyż można uznawać i afirmować istnienie Boga będąc jednocześnie dalekim od więzi osobowej z Nim. Zazwyczaj ma to miejsce tam, gdzie afirmacja istnienia Boga spleciona jest z jakimś postrzeganiem Jego natury i relacji do świata, postrzeganiem fałszywym oraz jawiącym się dla człowieka jako „coś” niegodnego, niemożebnego, obcego jego własnej naturze. Przykładem tego jest system filozoficzny Arystotelesa, gdzie istnienie Boga jest afirmowane, lecz jednocześnie rugowana jest religia jako coś nie mającego sensu, rzeczowej podstawy.

Jak zwracał na to uwagę E. Gilson, lwia część inteligencji na świecie, z racji braku elementarnego wykształcenia filozoficznego, nie ma pojęcia o tym, że zagadnienie Boga (Absolutu) to także i przede wszystkim problem ostatecznego wyjaśnienia rzeczywistości, centralna kategoria filozoficzna, zwieńczająca całokształt naturalnych ludzkich wysiłków poznawczych, składających się na naukę i kulturę ${ }^{30}$. Istnienie Boga (Absolutu), choć nieoczywiste i trudne do uchwycenia dla człowieka, jest, jak uczył tego już Arystoteles, istnieniem koniecznym dla wszystkiego (dla istnienia ruchu), bez którego także nie ma ludzkiego szczęścia i ostatecznego spełnienia się człowieka ${ }^{31}$.

Toteż edukacja i wychowanie jako rzeczywistości będące środkami prowadzącymi do dobra człowieka, muszą liczyć się z tym, bez czego nie istnieje ludzka dobroć, pełnia ludzkiego życia, tj. z Bogiem i samą religią. Jest to teza filozoficzna, wypływająca z rozumienia roli i funkcji kultury w życiu człowieka, ale także teza,

(jego woli i rozumu) dostrzegając tym samym racjonalny wymiar wiary i złączonego z nią życia religijnego. Edukacja, jako forma zdobywania prawdy przez człowieka, jest ze swej istoty nie tylko zawsze osadzona na wierze ludzkiej (zdolności do przyjmowania prawdy na mocy autorytetu nauczyciela, rodzica itp.), ale także jest otwarta na wiarę religijną. Bez prawdy wszelka postać wiary jest bezwartościowa, a $\mathrm{z}$ racji tego, że prawdę pojmuje tylko intelekt, stąd wierze, w tym wierze religijnej jest obca wszelka postać irracjonalizmu, fundamentalizmu, walki z rozumem i prawdą. Tam gdzie się one dokonują, tam nie ma wiary autentycznej, lecz jest fideizm.

30 Zob. É. Gilson, Bóg i ateizm, Kraków 1996, s. 143-148; tenże Jedność doświadczenia filozoficznego, Warszawa 2001.

31 Zob. Arystoteles, Etyka nikomachejska, Warszawa 1982; tenże, Zachęta do filozofii, w: tenże, Zachęta do filozofii. Fizyka, Warszawa 2010. 
która wprost stoi w sprzeczności z postulatami ateizacji kultury, wychowania, edukacji. Prowadzi ona także do odrzucenia laicyzmu oraz samej bezbożności.

Można dostrzec, że brak u współczesnego człowieka wiedzy o tych zagadnieniach, brak ich rozumienia jest spowodowany w pierwszej kolejności nieobecnością wiedzy filozoficznej, ale i także swoistym wywyższeniem się ponad wszystko poznania scjentystycznego, pozytywistycznego, niosącego obraz wartościowej wiedzy oraz edukacji. Niekiedy indyferentyzm religijny oraz pewna obojętność wobec problemu Boga mają swe wyjaśnienie w przykrych doświadczeniach, wynikłych z instrumentalizacji Boga i religii (np. zasada cuius regio, eius religio), które nie są przecież sprawą ani rzadką, ani też obojętną dla ludzkiej duchowości.

Należy także mieć na względzie i ten fakt, że w pedagogice od XIX wieku odrzuca się antropologię filozoficzną na rzecz nauk biologicznych o człowieku; neguje etykę na rzecz użycia wyników socjologii i psychologii, zwłaszcza behawioralnej; ugruntowuje cały proces edukacyjny i wychowawczy nie w mądrości i prawdzie, lecz w systemie woluntarystycznego prawa państwowego i polityki państwowej (np. józefinizm). To wszystko skutkuje utratą przez pedagogię jej tożsamości, będącej efektem przyporządkowania jej do dobra człowieka, nie zaś do tego, co zewnętrzne w stosunku do osoby ludzkiej.

Wielu pedagogów, a także osób bezpośrednio zaangażowanych w edukacji i wychowaniu (politycy, pracownicy uniwersytetów oraz ośrodków edukacyjnych i wychowawczych) posiada fałszywe przekonanie, że poznanie naturalne, reprezentowane przez naukę, musi milczeć o problemie Boga, bo ten leży jedynie w dziedzinie wiary religijnej. Idąc tą drogą rozumowania twierdzi się, że edukacja, która wiąże się z tym typem wiedzy i poznania wartościowego, naukowego, musi także być wolną od tez o Bogu, gdyż te należy pozostawić ludziom wiary, w dziedzinie ich subiektywnych przekonań. Sama zaś wiara religijna, jako wyrosła na zjawiskach i treściach poza naturalnych, raczej powinna być marginalizowana w kulturze, by ta mogła być opartą na rozumie, wiedzy, doświadczeniu, temu co sprawdzalne i intersubiektywne, temu co służy dobrobytowi i wygodzie, przyjemnościom większości tworzonej społeczności (ideologia oświeceniowa).

Przyczynkiem rugowania religii i problemu Boga z edukacji są też różnorodne przykłady konfliktów i sporów, jakie rodzą się na styku życia religijnego człowieka i polityki, medycyny, sztuki, ekonomii, prawa i wielu, wielu innych. W sporach tych bywają popełniane błędy przez wszystkie strony, często też bywają przekraczane kompetencje, które prowadzą do nieuprawnionych generalizacji. Jeśli dokonuje ich strona religijna, często po ukazaniu jej błędów dochodzi w świadomości potocznej nie tylko do odrzucenia samych błędnych twierdzeń i praktyk, ale także do odrzucenia samej religii i niesionych przez nią treści, praktyk.

Groźne nadużycia religii, choćby tak znane z przykładów sekt, ale i z racji skandali, jakie tworzą ludzie danej religii (niekiedy hierarchowie stojący na szczycie wspólnot religijnych), dostarczają jeszcze więcej argumentów za tym, że rugując z ludzkiej kultury religię, nie tylko przyczyniamy się do ogólnoludzkiego 
zjednoczenia świata, ale także do likwidacji jakiegoś istotnego zła, a nawet, jak niektórzy twierdzą, źródła największego zła, jakim jest religia i wszelka myśl o Bogu (R. Dawkins, P. Singer).

Zarysowane tu koncepcje wydają się stanowić jedno z zasadniczych źródeł rugowania Boga i religii z ludzkiej kultury oraz systemu wychowania i edukacji. Sprawiają one, że Bóg i religia są jakby „nowym i zarazem starym tabu” w kulturze, z którym należy się ostatecznie rozprawić wraz początkiem XXI wieku poprzez ateistyczną, laicką i bezbożną edukacje i wychowanie. Czy jednak jest to działanie słuszne?

Podejmowanie jednak jakiejkolwiek dyskusji z koncepcjami ateizującymi edukację i wychowanie zakłada ustalenie prawdy o tym, czym tak naprawdę jest sam ateizm oraz laicyzm, także sama religia i edukacja. Wymaga także jasnego i precyzyjnego pojmowania Boga oraz rozumienia dyskursu, którym posługujemy się podejmując całe zagadnienie ${ }^{32}$.

Warto tu także podkreślić potrzebę rozróżnienia teizmu jako pewnego stanowiska filozoficznego i światopoglądowego od faktu pobożności i religijności człowieka; obrony samej religii i prawa człowieka do niej od apologii konkretnej formy i treści wiary religijnej. Nie są to bowiem sprawy, które wprost ze sobą się utożsamiają, a zacieranie istotnych różnic między nimi nie tylko bywa przyczyną nieporozumień i konfliktów, ale szkodzi także samej edukacji, wychowaniu i autentycznemu życiu religijnemu człowieka ${ }^{33}$.

\section{Ateizm, jego rodzaje oraz związane $z$ nim aporie}

Sam termin ateizm jest pochodzenia greckiego i oznaczać może różne stanowiska i postawy ludzkie. Jak się zaznacza, „W kulturze greckiej ateiści - w znaczeniu współczesnym, jako negujący istnienie bogów — byli raczej nieliczni i egzystujący na marginesie życia społecznego i kulturowego. Najstarsze przykłady użycia słowa

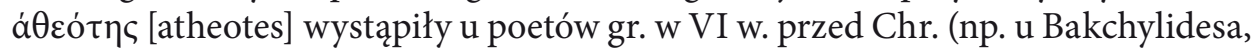

\footnotetext{
32 W myśl zasady sapientis est ordinare nie można się tu także obyć bez elementarnych dystynkcji i określeń, do których należy także odpowiedź na pytanie o to, czym jest wiara religijna, edukacja, natura człowieka, wychowanie, wreszcie relacja tychże do siebie i do dobra człowieka. Są to zagadnienia o charakterze filozoficznym i tylko filozofia, jako kompetentny rodzaj dyskursu, jest wstanie udzielić na nie wyczerpującej i trafnej odpowiedzi.

33 Warto tu także zaznaczyć, że omawiany problem ma znaczenie fundamentalne dla przyszłości cywilizacji Zachodu. Bywa on jednak mieszany z wieloma różnymi kwestiami, co często prowadzi do jego niezrozumienia i braku pogłębienia. Przykładem tego jest choćby mieszanie słusznej i stosownej krytyki ludzi religijnych (wierzących, hierarchów, księży) za ich faktyczne złe czyny z postawą antyklerykalną czy ateistyczną, co jest oczywistą pomyłką. Nie bez znaczenia jest tu także fakt i treść towarzyszących krytyce intencji, które mogą być dobre lub złe, stosowne lub nie, inspirowane autentyczną pobożnością lub nienawiścią do Boga, człowieka i religii.
} 
Pindara, Sofoklesa) na oznaczenie "opuszczenia przez bogów»" ${ }^{34}$. Poeci ci posługiwali się mitologiczną koncepcją boga jako istoty żywej, nieśmiertelnej, obdarzonej szczególną mocą i jakoś szczególnie związanej z człowiekiem i jego losem. Ateista był więc w znaczeniu pierwotnym kimś kogo bóg opuścił, a znakiem tego był jego zły los, często potęgowany przez własną nierozumność, będącą skutkiem utraty za sprawą bogów rozumu, bowiem, jak sądzono, quos Iuppiter perdere vult, dementat prius (kogo Iowisz chce zgubić, temu wpierw rozum odbiera).

Samo zaś stanowisko zwane ateizmem może być określone jako pewna postawa intelektualna i życiowa człowieka, mniej lub bardziej uzasadniona, w której człowiek neguje istnienie Boga (bogów). Bez istnienia bogów sama religijność jawić się może jako coś niemożebnego, stąd negacja istnienia bogów była także, lecz pośrednio, próbą odrzucenia religii. Areligijność czy nawet antyreligijność jakiegoś człowieka nie jest wprost ateizmem.

Zauważmy tu jednak sprawy istotne. Negacji istnienia Boga człowiek może dokonywać z różnych powodów, i może negacja ta dotyczyć albo boga pojętego mitologicznie, albo Boga, który sam się objawił człowiekowi (religii objawionej), albo też boga - pojętego filozoficznie (Absolut) - jako pewnej zasady uniesprzeczniającej świat. To powoduje, że mamy do czynienia $z$ wieloma rodzajami ateizmu: negującym istnienie bogów mitologii; $\mathrm{z}$ ateizmem filozoficznym negującym istnienie boga jako zasady bytowej świata; ateizmem negującym istnienie Boga, który jest Bogiem religijnym, Bogiem Objawienia.

Każdy też z tych ateizmów pociągał za sobą specyficzne konsekwencje. Ten, który atakował mity - głównie konsekwencje polityczne i kulturowe, gdyż bogowie mitologiczni byli postrzegani jako filary ładu społeczno-politycznego. Ateizm zaś o charakterze filozoficznym występował niezwykle rzadko, bowiem racjonalna i dorzeczna myśl ludzka skłaniała się najczęściej ku uznaniu jakiegoś czynnika wiecznego, nieskończonego i pierwszego, czyli czynnika posiadającego boskie przymioty, a zatem myśl ta skłaniała się ku teizmowi, ku afirmacji boga (Absolut) jako takiego.

Jeśli nawet w jakimś systemie o charakterze materialistycznym pojawiał się werbalnie sam ateizm, to najczęściej był to ateizm atakujący bogów mitologii, zaś systemowo dana teoria filozoficzna była teistyczna, głosząc choćby niezniszczalność, nieskończoność tego czynnika, który funduje materię (bytowość kosmosu, świata i człowieka) ${ }^{35}$. Taki ateizm jest odnajdywany u pierwszych greckich materialistów i w samym materializmie przez nich głoszonym, który skłaniał do kontestowania religijności ugruntowanej w mitach, lecz nie do negacji istnienia samego Absolutu jako takiego.

${ }_{34}$ Z. Zdybicka, Ateizm, w: Powszechna encyklopedia filozofii, t. 1. dz. cyt., s. 372.

35 Zob. na ten temat. W. Dłubacz, Problem Absolutu w filozofii Arystotelesa, Lublin 1992; tenże U źródeł koncepcji Absolutu. Od Homera do Platona, Lublin 2003; zob. M. A. Krąpiec, Metafizyczne poznanie, w; Powszechna Encyklopedia Filozofii, t. 7, red. A. Maryniarczyk, Lublin 2006, s. 90-101. 
Specyficzne konsekwencje pociągał za sobą również ateizm atakujący Boga religii, wśród których było przede wszystkim zanegowanie samej religii jako związku człowieka z Bogiem. Ten ateizm najczęściej był efektem konfesyjnej, apriorycznej postawy ludzkiej odrzucającej objawionego Boga, najczęściej z racji postrzegania go jako przyczyny ograniczenia człowieka. Jego źródeł należy upatrywać przede wszystkim w tkwiącej w człowieku inklinacji do pychy oraz w zabiegach antropomorfizujących Boga i deifikujących człowieka. Ten rodzaj ateizmu bywa często łączony z bezbożnością, która jednakże nie utożsamia się z ateizmem filozoficznym, czy ateizmem negującym mitologiczne bóstwa.

Zauważmy także pewne kwestie logiczne i filozoficzne, związane z rozumowaniem, które ma zwieńczyć koncepcja ateizmu. Fakt negowania czegoś nie musi prowadzić do nieistnienia tego, co się neguje, tym bardziej nieistnienia jakieś rzeczywistości całkowicie niezależnej bytowo od człowieka (Absolutu). Sąd o negacji istnienia czegoś może być efektem błęnych przesłanek, może być skutkiem alogiczności rozumowania, i - co ważne - nie ma mocy performatywnej (sprawczej, stwórczej), nawet gdy jest logiczny i opiera się na prawdziwych przesłankach. To, że ktoś swym sądem neguje istnienie czegoś, nie czyni tego, co jest, nieistniejącym. I na odwrót: to, że ktoś uważa, że coś istnieje, a to coś faktycznie nie istnieje, nie czyni realnym niczego na mocy wypowiedzenia sądu o istnieniu ${ }^{36}$.

Przywołanie tych kwestii, fundamentalnych dla realizmu poznawczego, pozwala uzmysłowić człowiekowi, że prawda o istnieniu lub nieistnieniu czegoś - jest jedynie przez człowieka poznawana, on sam nie jest jej ani miarą, ani kryterium. Kryterium tym jest rzeczywistość będąca przedmiotem poznania i sądzenia. Ateizm jako forma teorii negującej istnienie Boga ma swoje zatem kryterium w Bogu (bogach). Pytanie o to, gdzie i jak dokonuje się rozpoznanie istnienia Boga, to już kwestia inna niż sam ateizm, podobnie jak pytanie o to, jaką naturę posiada Bóg oraz jaka istnieje relacja świata do Boga.

W ogóle trzeba zaznaczyć, że wszelkie formy ludzkiego dowodzenia i uzasadniania zmierzają do afirmacji tego, co jest, nie zaś do udowadniania nieistnienia czegoś. O ile zatem ateizm jako stanowisko ludzkie może mieć wyjaśnienie psychologiczne (życiowe, wynikające z doświadczeń konkretnego człowieka), o tyle nie można przyjąć rozumowania: neguje istnienie $X$ a zatem $X$ nie istnieje lub też tezy: nie wierze $w$ istnienie $X$, a zatem $X$ nie istnieje.

Światopogląd człowieka, który podzielałby przekonanie o prawdziwości tychże tez, który by je w sobie niósł, w istocie rzeczy byłby światopoglądem irracjonalnym, właściwie dziecinnym, nie godnym poważnej uwagi, bo brak mu byłoby rozumności i oparcia na realnie istniejących faktach, stanach rzeczowych, prawach logiki ${ }^{37}$.

\footnotetext{
${ }^{36}$ Kryterium prawdziwości sądu pozostanie zawsze rzeczywistość.

37 Rozumność człowieka, jak ukazuje to antropologia, psychologia rozwojowa, z biegiem czasu zmienia się u poszczególnych ludzi. Piszący te słowa obserwuje szereg zmian w rozumności ludzkiej choćby przez fakt bycia rodzicem. Pragnie przywołać jedno z doświadczeń. Pewnego dnia jego syn
} 
Bliższa analiza światopoglądu jakiegoś myśliciela nazywającego siebie ateistą z łatwością wykazuje, że jest on najczęściej bezbożnikiem uwikłanym we własne sprzeczności i aprioryzmy; jego światopogląd nie jest wolny od fundamentalistycznych podstaw, często zaś jest efektem braku wykształcenia oraz uporczywej maniery przekraczania różnych kompetencji w połączeniu z redukcjonizmem.

Większość stanowisk ateistycznych to stanowiska irracjonalne, a nawet fundamentalistyczne. $U$ ich podstaw leżą nie tyle racje intelektualne, co wolitywne wybory, często aprioryczne, z którymi nie można racjonalnie dyskutować. Posługują się one rozumowaniami o charakterze sofistycznym, pseudologicznym, ukrywając szereg fałszywych przesłanek. Ma to miejsce szczególnie w przypadku ateizmu atakującego Boga religii. Ateiści twierdzą więc, że Boga nie ma, bo w niego nie wierza - czyżby zatem istniało tylko to, w co się wierzy? Głoszą częstokroć tezę, że nie wierza w Boga, bo sa "naukowcami”, a nauka nie odkryła istnienia Boga, więc Boga nie ma. Czyżby istniało tylko to, co odkrywa nauka? Czyż np. z racji tego, że dwieście lat temu biologia nie miała koncepcji kodu genetycznego, wynika, że kod ten nie istniał w żadnym organizmie żywym?

Można także postawić tu pytanie, czy w ogóle negacja Boga w postaci czy to ateizmu mitologicznego, czy filozoficznego lub religijnego jest działaniem uprawnionym na polu biologii, fizyki, chemii? Czy uczony może z racji swej profesji naukowej w ogóle głosić ateizm? Pojawienie się bowiem jakiś teorii u jakiegoś uczonego nie zawsze jest efektem rozwoju jego wiedzy naukowej, często bywa świadectwem przekraczania swych kompetencji naukowych. Przykładem tu choćby sytuacje, gdy fizycy badający początki przemian w Kosmosie zaczynają wkraczać w kompetencje teologów i dokonują reinterpretacji prawd wiary religijnej lub treści zawartych w Objawieniu; wkraczają na pole etyki pouczając o zasadach moralnych, a w filozofii i teodycei tworzą jakieś koncepcje zła, wolności lub też Bożej Wszechmocy i Opatrzności. To jawne przykłady przekraczania swych kompetencji, gwałcenia zasad metodologii nauki. Czy jednak należy je tolerować i mieć dla nich poważanie?

(Staś) po obejrzeniu bajki o smokach zapytał swego ojca o to, czy mógłby - podobnie jak bohater bajki - wytresować smoka i zaprzyjaźnić się z nim, na nim latać i walczyć. Ojciec z uśmiechem odpowiedział: „Stasiu, ale w świecie nie ma smoków, smoki nie istnieją”. Na to synek odpowiedział: To nic, że nie istnieją, ale czy mógłbym, czy mogę - ja chcę wytresować smoka. Cała opisana sytuacja obrazuje rozumność dziecka, w której można bawić się z smokiem, którego nie ma, który nie istnieje. Staś, z racji wieku (5 lat), nie widzi (nie rozumie), że warunkiem istnienia działania jest istnienie tego, co działa, że tylko istniejący smok może być tym smokiem, na którym się lata. Staś także, podobnie jak inne dzieci, „nie jest”, „nie istnieje” wtedy, gdy np. zamyka oczy i nie widzi świata, ukrywając się przed mamą lub koleżanką Natalią. To jest racjonalność normalna, ale dla dzieci; niestety bywa ona udziałem wielu profesorów i to nie tylko filozofii, którzy twierdzą, że jeśli oni czegoś nie widzą, nie rozumieją, nie wierzą w coś, to coś, na mocy ich aktów, nie istnieje. To jest częsta „logika” najbardziej znanych ateistów (np. R. Dawkins). „Logika” ta ubiera się w szaty naukowości i racjonalności, w istocie rzeczy kontynuuje ideologiczne działania marksistów, którzy po locie w Kosmos Gagarina mieli oznajmiać światu: Byliśmy w niebie i nie ma tam boga, a zatem naukowo udowodniliśmy ateizm. 
Czy należy je eksponować w systemie treści edukacyjnych? Czy wieńczący je ateizm ma być eksponowany w edukacji właśnie jako „owoc” naukowego poznania?

Absurdów ateistycznych postaw można z całą pewnością przedstawiać wiele, ale nie jest naszym zadaniem to teraz czynić. W tym kontekście warto tylko zauważyć, że poznanie naukowe obecne na polu fizyki, chemii, biologii - rzekomo usprawiedliwiające postawy ateizmu atakującego Boga religii - raczej dowodzi labilności wyników poznawczych, swej niedoskonałości, a także aspektowości, i co za tym idzie także swego ograniczenia, nie zaś konieczności i niezmienności. Jakże zmieniała się i zmieniać będzie ciągle fizykalna teoria materii, koncepcja atomu, czy też teoria początków Ziemi, Kosmosu, genomu itp. Historia danej nauki może dostarczyć tu całą masę argumentów za ostrożnością w ferowaniu ostatecznych rozstrzygnięć, może pobudzać do dostrzegania ograniczeń, jakie są udziałem poznania naukowego, choćby z racji przyjmowanego naukotwórczego pytania, aspektu badawczego, stosowanej metody, przyjętych założeń wyjściowych oraz zakładanych celów poznawczych ${ }^{38}$. Przede wszystkim jednak trzeba pamiętać, że wyniki nauk szczegółowych z racji tego, że są właśnie wynikami nauk szczegółowych nie mogą usprawiedliwiać tez dotyczących Boga, bo nie badają Boga i nie mogą tego czynić, bo Bóg nie jest ich przedmiotem badań, nie dysponują też adekwatnymi do tego przedmiotu metodami, ani też nie mają ze swej natury celu badania istnienia Boga ${ }^{39}$.

Ateizm zatem obecny u fizyka, biologa czy chemika nie ma fizykalnego czy biologicznego, ani też naukowego ugruntowania i wyjaśnienia, lecz posiada uzasadnienie często pozanaukowe w postaci arbitralnej decyzji człowieka lub też jest efektem zaangażowania się osoby w różne ideologie i błędy filozoficzne. Bywa także, że werbalnie głoszony, atakujący wprost np. Boga chrześcijan lub Boga muzułmanów, jest efektem i narzędziem walki religijnej, cywilizacyjnej. Ten bowiem, kto go głosi, faktycznie wyznaje jakąś wiarę w innego Boga (jest teistą, osobą wierzącą), a Boga chrześcijan czy muzułmanów uważa za fałszywego i zagrożenie dla swojego Boga. Można także dostrzec, że niejeden $\mathrm{z}$ ateistów jest nim $\mathrm{z}$ racji jednostronności swego podejścia, braków intelektualnych i edukacyjnych, złej woli, co czyni go zwyczajnie osobą głupią. Szacunek dla osoby nie może być mylony z poważaniem dla błędów i zła, tym bardziej zła poważnego, jakim jest ideologia tzw. naukowego ateizmu oraz doktrynerstwo zwalczające religię człowieka.

Zmienność wiedzy naukowej raczej powinna skłaniać do zastanowienia co do wartości poznawczej samej nauki, skłaniać do ostrożności, niż do ślepego zaufania uczonym, którzy częstokroć swawolnie przekraczają swoje kompetencje, gdy np. $z$ racji swej profesji badają organizmy żywe, by po chwili wypowiadać się na temat prawdziwości tez zawartych w Biblii, czy też działania Boga lub jakiegoś anioła.

\footnotetext{
38 Zob. Stanley L. Jaki, Bóg i kosmologowie, Racibórz-Wrocław 1995.

39 Zob. M. A. Krąpiec, Nauka a głupota, w: tenże, Człowiek kultura uniwersytet, Lublin 1998, s. $187-190$.
} 
Na szczęście człowiek dysponuje nie tylko poznaniem uzyskiwanym przez nauki szczegółowe, ale także poznaniem filozoficznym, które nie traci wartości i zachowuje walor konieczności i stałości. Jakże często u ateistów negujących Boga religii pojawia się działanie, które miesza, dajmy na to hipotezę istnienia ewolucji z jakąś formą dowolnej egzegezy tekstu Biblijnego, co ma „udawadniać”, że „Pismo Święte jest nieprawdziwe, więc Boga nie ma”. Jakże często hipoteza tzw. wielkiego wybuchu bywa stosowanym „argumentem” za nieistnieniem Boga oraz za brakiem Jego stwórczej działalności oraz za koniecznością przyjęcia teorii autokreacji, dokonanej przez - NICOŚĆ.

Tego typu praktyki dowodzą nie tylko fatalnej metodologicznej kondycji ateistycznych uczonych, ale są ich naukową kompromitacją, także są świadectwem ich marnego wykształcenia ogólnego, mizernej lub też całkowicie wybrakowanej edukacji filozoficznej oraz uśpienia zdrowego rozsądku. Popularność, jaką sobie zyskują w mediach, jest efektem niskiego stanu wiedzy filozoficznej u odbiorców mediów, co dowodzi braku elementarnej kultury logicznej.

Te same braki, jeśli nie większe, są udziałem prawodawców i polityków postulujących wprowadzenie edukacji ateistycznej; rodziców przyzwalających na jej funkcjonowanie; nauczycieli realizujących model edukacji ateistycznej ${ }^{40}$. Wielkie zadanie w tym kontekście posiadają uczelnie, gdzie kształtuje się rozumienie wyżej przedstawionych kwestii, również sami filozofowie, którzy z racji swego wykształcenia mają szansę dać świadectwo prawdzie i tym samym odpór dla błędów.

\section{Bezbożność i laicyzm}

Podejmując problem ateizacji edukacji musimy mieć świadomość, że w praktyce łączy się ona, lecz nie utożsamia, z bezbożnictwem, czyli pewną postawą usuwającą Boga religii z ludzkiego życia, wraz z Jego prawami, nauką. Bezbożność jest rodzajem postawy ludzkiej złączonej z pogardą dla Boga i Jego praw, nauki, często także z wrogością i zuchwałością wobec spraw Bożych i tego, co się wprost do nich odnosi.

Zauważmy tu, że choć sami bezbożnicy określają się jako ateiści, to jednak w sensie ścisłym nimi nie są. Są oni raczej przeciwnikami Boga i religii i poniekąd dają dowód pośredni przywiązania do teizmu, nie zaś do ateizmu. Nie można bowiem przy zdrowych zmysłach walczyć z czymś, co uważa się za nieistniejące. Jeśli uważa

\footnotetext{
${ }^{40}$ Co w obliczu tego zła należy czynić? Wydaje się, że przede wszystkim dwie rzeczy: intensyfikować, gdzie tylko można, autentyczną edukację filozoficzną (metafizyczną) oraz upowszechniać wszędzie dobrą wiedzę teologiczną, kulturę teologiczną prowadzącą do poznania Boga i odrzucenia fałszywych Jego obrazów lansowanych przez ateistów. Ten drugi rodzaj aktywności musi być poprzedzony autentyczną pobożnością; pierwszy powinien być złączony z dobrą edukacją historyczną, bo zawsze pozostanie aktualne przesłanie, że historia magistra vitae est. Zob. M. A. Krąpiec, Człowiek kultura uniwersytet, Lublin 1998, s. 149-277; tenże, Filozofia co wyjaśnia? Filozofia w teologii, Lublin 2000.
} 
się, że żaden Bóg nie istnieje, a mimo to organizuje się batalie przeciw Niemu i całej ludzkiej religii, to należy przyjąć, że sam ateizm jest pewnym urojeniem ludzkiej psychiki lub też jakąś postacią głupoty, bądź też jakąś postacią zakamuflowanej walki i propagandy.

Zauważmy również, że bezbożność jest elementem światopoglądu i ideologii jakiegoś człowieka lub grupy ludzkiej, często związanego z antyklerykalizmem (wrogością wobec duchowieństwa, ludzi religijnych, reprezentujących religię). Bywa ona często wspierana przez tzw. laicyzm, stanowisko głoszące potrzebę usunięcia religii i instytucji religijnych z życia społecznego. Niekiedy staje się bezbożność podstawą dla działań zbrodniczych, ludobójczych (zbrodnie rewolucji francuskiej, bolszewizmu, narodowego socjalizmu, Czerwonych Khmerów).

Laicyzm jeśli w ogóle godzi się na istnienie religii, to widzi w niej raczej przejaw starej i nieracjonalnej tradycji kulturowej, która powinna być zamknięta jedynie do prywatnego życia jednostek, zaś to, co wspólnotowe, państwowe i społeczne, musi być przed religią chronione, od niej separowane. Rozdział religii od kultury społecznej, społecznego wymiaru życia ludzkiego to postulaty wywodzące się z laicyzmu, które przygotowują grunt do ogólnego życia areligijnego, braku Boga w całej kulturze. Czynią to w nadziei, że sama religia, jak i myśl o Bogu, zostanie porzucona w kulturze (obumrze), występując jedynie jako archaiczna zaszłość, ciekawostka historyczna, troszkę wstydliwa, odrzucona przez postępową, racjonalną i naukową ludzkość.

Tym, co również charakterystyczne dla laicyzmu, co łączy go z bezbożnictwem $i$ ateizmem religijnym, to traktowanie wiary religijnej jako przejawu nieracjonalnego życia emocjonalnego człowieka. Religia jest więc tu jedynie sferą irracjonalnych uczuć i przeżyć, a te trzeba dla dobra człowieka tonizować i sukcesywnie usuwać, bo odbierają one zdaniem zwolenników laicyzmu człowiekowi rozum. Religia w swej istocie jest tu postrzegana jako czynnik alienujący, a nawet działający narkotycznie i nihilistycznie. Człowiek zaś bez rozumu, nie jest człowiekiem, a zatem dla dobra ludzi trzeba strzec ich i „leczyć” z religijnych uniesień. To zdaniem ideologów laicyzmu konieczne zadanie systemu edukacyjnego i wychowawczego. $Z$ tej racji wychowanie i edukacja są w ich mniemaniu bliższe ateizmowi niż teizmowi. Strzec ich ma państwo, które jest nie tyle tolerancyjne dla religii, co areligijne, laickie i nakierowane na materializm, ateizm.

Nie może zatem dziwić fakt, że zwolennicy laicyzmu zawierają intelektualne sojusze z wszelkiej maści ateistami, że tolerują, jeśli nie wspierają bezbożność i to wszystko co do niej prowadzi, jak pornografia, narkotyki, przemoc, konsumpcjonizm, hedonizm, utylitaryzm ${ }^{41}$.

${ }_{41}$ Odnosi się do głownie do laicyzmu obecnego w kulturze Zachodu, nie zaś do tego, jaki np. istnieje w Azji u Czerwonych Khmerów, czy maoizmie; zob. A. W. Jelonek, Rewolucja Czerwonych Khmerów 1975-1978. Studium autarkicznego rozwoju, Warszawa 1999. 
Laicyzm będzie także wykorzystywał rozważania ateizujących filozofów i jednocześnie bronił dostępu do edukacji i wychowania filozofii klasycznej, metafizycznej i związanej z nią etyce cnót. Będzie, na ile tylko mógł, promował indywidualistyczny model antropologii, z jego subiektywizmem, egotyzmem, relatywizmem i utylitaryzmem. Jego hasłem naczelnym będzie też wolność od wszystkiego i do wszystkiego, stąd edukacja i system wychowania ma przygotować i umożliwić to, czym chce być człowiek, nie zaś to kim jest. Stąd też, z jednej strony, będzie on zwalczał wszelkie koncepcje głoszące stałość ludzkiej natury i jednocześnie będzie optował za ideologią gender, socjologizmem, psychologizmem, ekonomizmem, słowem tym wszystkim, co relatywizuje naturę ludzką, czyniąc ją niepoznawalną i nieokreśloną.

W budowie modelu życia społecznego pójdzie za totalitarnymi elementami ideologii kolektywistycznej, która gardząc przyrodzoną godnością osoby ludzkiej, jej prawami, odda życie społeczne tyranii nierozumnej woli większości (demokracja), wszechmocy woluntarystycznego prawa bez dobra godziwego (pozytywizm prawniczy i woluntaryzm prawny), despotyzmowi utylitaryzmu i pragmatyzmu w każdej dziedzinie (ekonomizm). Są to konsekwencje intelektualnych wyborów i postaw ideologii laicyzmu, kolaborującego z bezbożnością, ateizmem religijnym. Często łączy się on z sympatiami do ruchów wolnomyślicielskich, iluminizmu, masonerii, podzielając ich antyklerykalizm, ideologie sekularyzacji oraz wiarę w człowieka, jego moc, jeśli nie wszechmoc. Rysem jego zasadniczym i poniekąd probierzem jest również negatywny stosunek do chrześcijaństwa i jego cywilizacyjnego i kulturowego dziedzictwa.

Przedstawienie powyżej zarysowanych problemów wydaje się być konieczne dla zrozumienia efektów, jakie przynosi edukacji i wychowaniu ateizm. Bywa on bowiem nie tylko faktycznie jakąś postacią ateizmu, lecz także formą wprowadzenia do szkół bezbożności, laicyzmu, areligijności, sekularyzmu ${ }^{42}$. Nade wszystko jednak jest on rozsadnikiem irracjonalizmu i tego wszystkiego, co dewastuje dziedzictwo cywilizacyjne kultury Zachodu, wyrządzając niepomierne szkody samemu człowiekowi. Ale czy rzeczywiście postulaty ateizacji edukacji i wychowania są dziś obecne w kulturze?

\section{Ateizacja i bezbożnictwo oraz ich praktyczne formy realizowania w szkole (wybrane przykłady)}

Doniesienia prasowe przekazują wiadomości o tym, że np. w Irlandii, kraju uważanym za silnie religijny (katolicki), władze państwowe wprowadzają obowiązkowe zajęcia lekcyjne $\mathrm{z}$ ateizmu we wszystkich szkołach publicznych. Z lekcji

42 Zob. A. Niemancewicz, Bolszewizm a wychowanie, Lublin 1929. 
tych mają być zwolnione jedynie szkoły prowadzone przez podmioty wyznaniowe, ale i one, prędzej czy później - jak można sądzić - staną przed presją przyjęcia wyznaczonych przez prawo państwowe laickich i ateistycznych "standardów” kształcenia i wychowania.

Według projektów ateizacja w Irlandii ma się dokonywać systematycznie w 10-ciu modułach, cotygodniowo, na lekcji trwającej około 40 minut. Co ciekawe, lekcje ateizmu mają być skierowane do bardzo małych dzieci, już od czwartego roku życia oraz dorastającej młodzieży (13 lat), a zatem osób niedojrzałych intelektualnie, moralnie, emocjonalnie, kulturowo, religijnie i społecznie. To sprawia, że projekt ateizacji już u swego założenia występuje nie jako dojrzałe i krytyczne kształcenie, związane z wyrobieniem u człowieka dojrzałości w rozumieniu prawdy, ale specyficzny rodzaj indoktrynacji i ideologizacji (bezbożnictwa), który ma negatywnie nastawić dzieci i młodzież do Boga i religii. Dlaczego? Wynika to z przekonania, że religia i Bóg są złem, i tak jak trzeba chronić dzieci przed wypadkami, zarazą, tak trzeba je chronić przed Bogiem i religią. Oto założenie, które przyświeca ateizacji i krzewieniu bezbożności ${ }^{43}$.

W Irlandii koordynatorem i podmiotem działań ateizujących ma być państwo i jego organa wsparte stowarzyszeniami (między innymi Atheist Ireland oraz Educate Together), programowo (na co dzień i od święta) ateizującymi kulturę. Lekturą ma być książka Magia realizmu autorstwa Richarda Dawkinsa, biologa i ateisty, negującego każdą religię, zwolennika nowego porządku kulturowego bez Boga.

Zdaniem tego myśliciela religia i Bóg są źródłem wszelkiego zła (root of all evil), sam zaś Bóg jest niebezpiecznym urojeniem (the God delusion), z którego należy wyzwolić i leczyć człowieka ${ }^{44}$. Co przerażające, ateizm, materializm, antyreligijność oraz antyklerykalizm łączy on z otwartością na pozytywne przyjmowanie praktyk pedofilskich, gdyż jak twierdzi „nie jest w stanie potępić łagodnej pedofilii, w tym nauczyciela sadzającego go na kolanach i wkładającego ręce do jego spodenek"45.

Ideowym podłożem koncepcji Dawkinsa jest scjentyzm, złączony z marksistowskimi koncepcjami kultury, alienacji, progresu powiązanego z obsesyjną nienawiścią do chrześcijaństwa, a także z przekonaniem, że wszelka religijność człowieka jest zjawiskiem patologicznym, chorobowym i stanowiącym zaczyn wszelkiego zła.

Ukazanie tylko tych elementów projektu ateistycznej edukacji musi przerażać, ale to nie koniec patologicznych pomysłów na „reformę szkoły”. Jak można

\footnotetext{
${ }^{43}$ Propagatorzy tego typu działań usprawiedliwiają je wolnością sumienia człowieka, prawami do kształtowania dzieci w duchu zasad wyznawanych przez ateistycznych rodziców, prawami człowieka do wolności od religii oraz szeregiem innych stanowisk i koncepcji, których w tym miejscu prezentować nie sposób, a które jeśli nie są efektem intelektualnych pomyłek, są manifestacją absurdów nie mających nic wspólnego z prawdą i dobrem człowieka.

${ }^{44}$ Zob. R. Dawkins, Bóg urojony, Warszawa 2007, s. 59; zob. tamże s. 16n.

45 Informację podaje za: http://narodowcy.net/religia/8125-irlandia-obowiazkowe-lekcje-ateizmu, (dostęp: 29. 07. 2014).
} 
przypuszczać, ateistyczna, a de facto bezbożna edukacja w irlandzkich szkołach publicznych będzie korespondowała z wytycznymi WHO dotyczącymi modelowania samego procesu edukacyjnego oraz obecnych tam treści i metod, które faktycznie zmierzają do seksualizacji dzieci i młodzieży.

Wytyczne te są także w Polsce oraz w innych krajach UE przedmiotem wnikliwej uwagi świata nauki i polityki. Są przyjmowane przez niektórych jako przyczyna wzorcza do kształtowania reform edukacyjnych i wychowawczych. Toteż sądzi się i zarazem akceptuje stan rzeczy, w którym w szkole będzie mógł mieć proces promocji masturbacji i pornografii, różnych „niekonwencjonalnych” form realizacji popędu płciowego, antykoncepcji, aborcji oraz wielu innych patologii, które do tej pory były postrzegane jako złe głównie z powodów moralnej oceny ${ }^{46}$. Przez wieki praktyki te w świadomości moralnej ludzi miały swą pejoratywną ocenę moralną, ale też sankcje religijne. Skoro zatem jest przyzwolenie na ateizm oraz bezbożność,

46 W Polsce proces ten ma swoich zwolenników i obrońców w ministerstwach oraz na szczytach decyzyjnych polityki dotyczącej nauki. Warto tu na dowód przytoczyć notatkę prasową z gazety Rzeczpospolita, gdzie czytamy, że „Konferencja odbyła się wczoraj (22-04-2013 - P.S.) w siedzibie Polskiej Akademii Nauk. Razem z PAN i dwoma ministerstwami organizowała ją agenda ONZ ds. Rozwoju oraz polskie biuro Światowej Organizacji Zdrowia (WHO). Była poświęcona prezentacji „standardów edukacji seksualnej w Europie”, które WHO opracowało z niemieckim Federalnym Biurem ds. Edukacji Zdrowotnej. Prezentował je konsultant krajowy w dziedzinie seksuologii prof. Zbigniew Lew-Starowicz. Dużą część wykładu poświęcił seksualności dzieci. Wywodził, że nie są one aseksualne, bo z badań wynika, że już niemowlęta doznają orgazmów. Podobne wnioski płyną z opracowania WHO. Wynika z niego, że „rozwój seksualności rozpoczyna się w momencie urodzenia", więc edukację należy rozpocząć przed czwartym rokiem życia. W tym okresie dziecko należy nauczyć umiejętności, takich jak „rozmowa dotycząca prokreacji z wykorzystaniem określonego słownictwa”. Dziecko powinno umieć też „wyrażać własne potrzeby, życzenia i granice, na przykład w kontekście zabawy w lekarza". Standardy WHO określają, co w dziedzinie seksu powinny umieć dzieci w kolejnych przedziałach wiekowych. Między 9. a 12. rokiem życia dziecko powinno nauczyć się już „skutecznie stosować prezerwatywy i środki antykoncepcyjne w przyszłości”. Powinno też umieć „brać odpowiedzialność za bezpieczne i przyjemne doświadczenia seksualne”. WHO radzi, by dziecko miedzy 12. a 15. rokiem życia potrafiło samo zaopatrywać się w antykoncepcję. Zdaniem WHO młodzieży w wieku powyżej 15. roku życia można dodatkowo wpoić „krytyczne podejście do norm kulturowych/religijnych w odniesieniu do ciąży, rodzicielstwa itp.”. W konferencji uczestniczyli przedstawiciele resortów zdrowia i edukacji. Nie są to standardy, które będą wdrażane w szkołach. To jedynie dyskusja na ten temat - powiedziała „Rz” po konferencji wiceminister edukacji Joanna Berdzik. W trakcie dyskusji mówiła jednak, że chce „rozpowszechnić ten raport wśród nauczycieli i rodziców", a inna z przedstawicielek MEN opowiedziała się za publikacją opracowania na jednym z portali dla nauczycieli. Standardy pozytywnie oceniła też Dagmara Korbasińska z Ministerstwa Zdrowia. - Chcemy popularyzować ten przewodnik - zaznaczyła. Profesor Zbigniew Lew-Starowicz tłumaczy, że celem konferencji nie było zachęcanie 12-latków do seksu. - Optymalny wiek rozpoczęcia takiej aktywności to około 20 lat. Co natomiast zrobić z tymi, którzy decydują się na to o wiele wcześniej? - pyta. Jednak zdaniem konserwatywnych polityków standardy, które zachwalali wczoraj przedstawiciele rządu, w praktyce zachęcają do wczesnych eksperymentów z seksem. - W ten sposób jedynie rozbudza się wyobraźnię seksualną, zamiast ją kształtować - tłumaczy Jacek Żalek z PO”, podaję za http://www.rp.pl/artykul/1002779.html (dostęp: 12.08. 2014). 
a religia nie ma sensu i znaczenia, to powinny one być traktowane jako „normalny” element życia ludzkiego. Oto konsekwencje tworzenia ateistycznego systemu edukacji na bazie ideologii postępu, laicyzmu, materializmu i naturalizmu.

Dawkinsa i jemu podobnych wspierają w ateistycznych pomysłach także „etycy” (np. Peter Singer), głoszący konieczność ucieleśniania wolności wszystkich do wszystkiego, w tym także wolności i praw zwierząt ${ }^{47}$. Ów zwolennik legalizacji i stosowania aborcji, eutanazji, (w razie potrzeby) orędownik likwidacji po urodzeniu nienarodzonych dzieci, o ile nie mają one świadomości, obrońca prawa do samobójstwa ludzi zdrowych, jak i chorych, zwolennik przełamywania „tabu zoofilii", promotor hedonizmu i utylitaryzmu, widzi w religii i obecności samej idei Boga zasadnicze przeszkody dla zaistnienia „wolności wszystkich do wszystkiego" ${ }^{48}$. Jego zdaniem autentyczna edukacja musi wiązać się nie tylko z promocją zarysowanych powyżej stanowisk, ale kształtowaniem nowego rozumienia moralności, gdzie największym złem jest ból, cierpienie. Moralność ta ma obejmować wszystkie istoty żywe, nie tylko ludzi, stąd człowiek, który rości sobie prawo do władztwa nad światem (innymi gatunkami i istotami żywymi), jest tylko niebezpiecznym uzurpatorem i tyranem.

Zdaniem Singera autentyczna edukacja musi pozbawić człowieka tych despotycznych zapędów i przyczynić się do odrzucenia praktyki życiowej, w której zadajemy ból, uśmiercamy inne istoty zdolne do cierpienia. Czyniliśmy to głównie $\mathrm{z}$ racji religijnego światopoglądu, predestynującego człowieka do sprawowania władzy nad światem, władzy danej człowiekowi przez Boga w myśl przykazania „Czyńcie sobie ziemię poddaną" (Rdz 1, 28).

Na gruncie tak ukształtowanego spojrzenia na świat i człowieka łatwo pojawić się może wreszcie teza, że zasadniczą drogą do uwolnienia świata od cierpień jest uwolnienie świata od rodzaju ludzkiego lub też takie jego ograniczenie, które da szanse życia organizmom pozaludzkim (John Paul Holdren) ${ }^{49}$. Z tej racji promo-

47 Zob. P. Singer, Wyzwolenie zwierząt, A. Szczęsna, Warszawa 2004.

48 P. Singer wyjaśnia, że „religia nadal jest główną przeszkodą na drodze do reform, które wielu ludziom na całym świecie przyniosłyby ulgę w cierpieniu. Pomyślcie tylko przez chwilę o sprawach takich jak skuteczne zapobieganie ciąży, aborcja, pozycja kobiety w społeczeństwie, wykorzystywanie embrionów do badań naukowych w medycynie, wspomagane samobójstwo, postawy wobec homoseksualistów i traktowanie zwierząt. W każdym z tych przypadków, gdzieś w świecie, przekonania religijne są przeszkodą na drodze do zmian, które uczyniłyby świat bardziej przyjaznym, bardziej ludzkim i bardziej wolnym. Dlatego musimy chronić swoją wolność i swoje prawo do zaprzeczania istnieniu boga, a także do krytyki nauczania Jezusa, Mojżesza, Mahometa i Buddy, które poznajemy z ksiąg przez miliardy ludzi uważanych za święte. Co więcej, ponieważ czasem trzeba pewnej dozy humoru, by upuścić powietrza z balonu świątobliwej pobożności, wolność słowa musi obejmować wolność do kpin i szyderstw"; cytuję za: http://www.przeglad-tygodnik.pl/pl/artykul/prawo-doniedorzecznosci (dostęp: 10.08. 2014).

49 John Paul Holdren to bardzo ważny i wpływowy doradca prezydenta USA Baraka Obamy, futurolog, polityk i wizjoner rozwoju cywilizacyjnego świata, dyrektor Office of Science and Technology Policy. Posiada on ogromy wpływ na kształtowanie się i zarządzanie polityką dotyczącą technologii, 
cja ideologii depopulacji oraz „troski o środowisko naturalne” łączą się ze sobą w procesie edukacyjnym. Ale ich faktyczne wdrożenie napotyka ciągle na opór ze strony ludzi religii, ze strony kultury religijnej, w której człowiek występuje jako gospodarz świata, danego mu do rozumnego użycia przez Boga. Stąd walka $\mathrm{z}$ religią jest walką o prawo postępu, o zmniejszenie zanieczyszczeń środowiska naturalnego, o uczynienie z całego świata rzeczywistości pokojowej bez granic, dyskryminacji, wolnego od zamieszek i biedy. Niezbywalną rolę w projekcie tym ma ateistyczna, a faktycznie bezbożna edukacja, która likwiduje „uzurpatorstwo ludzi” do sprawowania władzy nad przyrodą.

Jak można przypuszczać, edukacja ta będzie przebiegać różnymi ścieżkami, jednakże jej zasadniczy charakter zostanie zawarty w pewnym sofistycznym paradygmacie rozumowania i oceniania, kształtowania oraz wytwarzania w człowieku pewnych koncepcji, postaw, sądów, sprawności, ale i ostatecznie działań. Ich sednem ma się stać odrzucenie przez człowieka Boga, religii, postawa negatywna wobec teizmu i życia duchowego człowieka związanego z pobożnością.

Trzeba tu podkreślić, że zasadniczy charakter procesu edukacyjnego jest wyznaczony nie tylko przez cele, ale także przez metody, które w istocie swej są formą ideologizacji i manipulacji człowiekiem. Są one zatem jawnym dowodem pogardy dla godności ludzkiej, wolności i rozumności, jaka jest udziałem ludzi. Zostały one już nakreślony przez wrogich religii i Boga wolnomyślicieli oświecenia, a następnie utopistów dziewiętnastego wieku, zmierzających do wyzwolenia ludzkości z wszelkich krępujących ją ograniczeń, oraz do budowy swoistego laickiego „raju na ziemi”. Były one także w dwudziestym wieku wsparty przez nienawistnych tradycji chrześcijańskiej i w ogóle religijnej ideologów, uwiedzionych scientyzmem, nowożytną koncepcją progresu i laickiej kultury, w której panuje dowolność umożliwiająca nieskrępowane korzystanie z wszelkich przyjemności.

Praktyki ludobójcze, działania eugeniczne, jak i tworzenie totalitarnego ładu społecznego, oto kontekst realny i historyczny funkcjonowania edukacji ateistycznej i krzewiącej bezbożność choćby w Rosji Radzieckiej, hitlerowskich Niemczech, komunistycznych Chinach, Kambodży ${ }^{50}$. Czyżby zatem przez ateizm i bezbożnictwo społeczności ludzkie tworzące Zachód pragnęły wkroczyć na drogę Rosji Radzieckiej, Hitlera, Pol Pota i Mao? Należy mieć nadzieję, że do tego nie dojdzie i że tym samym to, co nazwane jest słusznie cywilizacją śmierci, zostanie przez

edukacji i wielu, wielu dziedzin życia gospodarczego. Jest zwolennikiem utylitaryzmu, hedonizmu, ideologii depopulacji, traktowania rozrostu liczby ludzi na świecie jako czołowego zagrożenia, z którym musi poradzić sobie USA, jak i każdy rząd na świecie.

50 Co godne podkreślenia, stosowanie edukacji ateistycznej na Zachodzie cieszy szczególnie tych, którzy są z racji cywilizacyjnych wrogo nastawieni do Zachodu i jego kulturowego fundamentu, jakim jest chrześcijaństwo. Mają oni świadomość, że usunięcie go jest w praktyce nie tylko odcięciem kultury Zachodu od jej życiodajnych korzeni, ale także jest pozbawieniem realnego i zarazem historycznego fundamentu, elementu tożsamościowego, konstytutywnego, bez którego Zachód istnieć nie może. 
ludzi Zachodu porzucone w całości, również w wymiarze edukacyjnym i wychowawczym. Nie jest to jednak zadanie łatwe do spełnienia, zwłaszcza z racji braku u wielu osób elementarnego wykształcenia filozoficznego.

Zajęcia $\mathrm{z}$ ateizmu jako część procesu edukacyjnego są jednak znane i praktykowane w pewnych regionach USA ${ }^{51}$ i UE ${ }^{52}$. Nie brak również ich zwolenników i w Polsce, wśród osób związanych z ministerstwem edukacji narodowej ${ }^{53}$. Ateizm

51 Do znanych propagatorów ateizmu w USA zaliczyć należy Michael L. Martina, który wyjaśniał, $\dot{z} \mathrm{e}$ „My object is to show that atheism is a rational position and that belief in God is not. I am quite aware that atheistic beliefs are not always based on reason. My claim is that they should be”, tenże, Atheism: A Philosophical Justification, Philadelphia, PA 1990, s. 24. Poświęcił on wiele uwagi i czasu na przeanalizowanie istniejącej w języku angielskim w USA literatury skierowanej do dzieci, a służącej promocji ateizmu, a de facto bezbożnictwa. Mechanizm tej promocji w szkole jego zdaniem powinien być stosunkowo prosty. Należy w pierwszym rzędzie zaliczyć religię i wszelką koncepcję Boga do dziedziny zmyśleń, bajek, mitów, legend, fikcji itp. (Bóg i religia ma się znaleźć w kategorii takich rzeczy, jak wróżki, magia, astrologia czy też przepowiadanie przyszłości z fusów z kawy). W dalszej kolejności trzeba wykazać, że zmyślenia te są nieracjonalne w świetle racjonalności niesionej przez współczesne nauki (fizykę, biologię, chemię) oraz wykazać, że są one przynajmniej w niektórych wypadkach niebezpieczne i sprawiające jakieś postacie zła. Dziecko (młodzieniec) ma podzielić przekonanie, że ze złem należy walczyć, a zatem należy walczyć także z jego „rozsadnikami”, jakimi są religia i wszelka myśl człowieka o Bogu. Stąd młody człowiek również i dziecko mają wynieść przekonanie, że religia i Bóg są jego zagrożeniami i zagrożeniami dla społeczności ludzkiej. Jeśli są one tolerowane, to głownie z racji kulturowych. M. L. Martin wskazuje także, że skuteczna droga do ateizacji (bezbożnictwa) wiedzie przez promocje w dzieciach i młodzieży sceptycyzmu, agnostycyzmu, relatywizmu, subiektywizmu, krytycyzmu, nowożytnego antropocentrycznego humanizmu, przez ukazywanie patologicznych przykładów nadużywania religii i funkcji religijnych, teorię ewolucji, wreszcie przez zwrócenie uwagi na fakt zła w świecie, ludzką wolność i niemożność pogodzenia ich z istnieniem Boga jako racji istnienia świata. Jego zdaniem dzieci i młodzież z zajęć ateistycznych mają wynieść przekonanie, że reprezentują wolną i postępową część społeczności ludzkiej, która jednocześnie jest atakowana przez większość podległą myśleniu i przekonaniom religijnym. Stąd autentyczny ateizm i ateistyczna edukacja wymaga postawy „wojownika" gotowego dzielnie bronić ateizmu, laicyzmu i wszelkich elementów z nimi powiązanych. Jest to postawa także „świeckiego” racjonalistycznego misjonarza, który swą działalnością otwiera drogę do wolności innych. Postawa ta związana jest z ukształtowaniem w sobie negacji autorytetów i otwarcia na wolnomyślicielstwo; zob. tenże Atheistic education w: http://infidels.org/library/ modern/michael_martin/education.html (dostęp: 28. 08. 2014). M. L. Martin szczególnie mocno atakuje w swych publikacjach chrześcijaństwo, wskazując na niemożność „naukowego” ujęcia jego dogmatów (prawd) oraz praktyki życiowej.

52 Zob. P. Bernardin, Machiavel nauczycielem, Komorów 1997.

53 Jak donoszą media „W ostatnich tygodniach lewicowa część mediów i tzw. autorytetów podniosła krzyk na podpisywaną przez lekarzy Deklarację Wiary, w której uznawali prymat Prawa Bożego. W internecie pojawił się apel, by podobne deklaracje mogli składać nauczyciele. Minister edukacji podkreśliła w rozmowie z PAP, że polskiej szkole potrzebna jest neutralność światopoglądowa. Mam nadzieje, że ten dokument pozostanie wyłącznie w sferze projektu. Mam nadzieje, że nie stanie się przyczynkiem do rozpętania jakiejś wojny religijnej w polskiej szkole — powiedziała Kluzik-Rostkowska. Zaznaczyła, że szkoła publiczna w Polsce na mocy konstytucji i różnych innych aktów prawnych, m.in. ustawy Karta Nauczyciela, ma być szkołą neutralną światopoglądowo. Łatwo sobie wyobrazić sytuację, w której za deklaracja, o której w tej chwili mówimy, swoje deklaracje będa chcieli mieć przedstawiciele innych wyznań, którzy również sa nauczycielami i pracuja w polskich szkołach. Na końcu tej drogi możemy mieć całkiem niemała, poważna wojną religijną, w którą zostana 
ten, ukryty i wsparty czy to postulatami antyklerykalnymi, czy to wyznawaną ideologią laickości lub też wprost nienawiścią do religii w ogóle, a do chrześcijaństwa w szczególności, staje się ideowym gruntem formacji treści edukacyjnych i zapleczem do określania celów i metod całego procesu edukacyjnego i wychowawczego $^{54}$. Towarzyszy mu obłudna frazeologia walki o wolność, konieczności obrony tolerancji, potrzeba budowy laickiego społeczeństwa i życia ludzkiego w ogóle. Jakie jest jednak ideowe ugruntowanie tego typu działalności? Co jednak stoi za tego typu działaniami? Odpowiedź nasuwa się sama: nienawiść do człowieka jako takiego oraz pogarda dla tego, kto jest źródłem istnienia wszystkiego - Boga ${ }^{55}$.

Tradycja kultury Zachodu i to nie tylko ta, która związana jest z chrześcijaństwem, od zarania swych dziejów szła za wskazaniami Pitagorasa, który już sześć wieków przed Chrystusem pouczał, że „Wszystko, co dobre płynie strumieniem z dłoni bogów. Wychowując przeto młodzież do bogobojności, wychowywać ją będziesz do dobrego. Człowiek podobny ma być do Boga, a będzie do niego podobny, jeśli ukocha prawdę, piękno i cnotę. (...) Dziecię każde jest swym rodzaju podobne do bóstwa; podawaj mu rękę, dozwól rozwijać się samodzielnie jego duchowi" 56 . Oto właściwa dla Zachodu cywilizacyjna treść i zasada, które leżała u podstaw edukacji i wychowania.

Była zatem w kulturze Zachodu obecna od jej zarania troska o uszlachetnienie ludzkiej paidei przez związek człowieka z Bogiem, była otwartość na życie religijne, które jawiło się jako najwyższy element formacji duchowej człowieka, element poniekąd najważniejszy, gdyż prowadzący cały byt ludzki ku ostatecznemu przeznaczeniu. Nie mogła elementu tego zabraknąć w dobrze urządzonej ludzkiej

wplatane dzieci. Zupetnie nie wyobrażam sobie takiej sytuacji. Będę robić wszystko, by neutralność światopoglądowa polskiej szkoły została zachowana - zadeklarowała. Według Kluzik-Rostkowskiej, jeżeli nauczyciel podpisze taką deklarację i będzie uczyć zgodnie z zapisami w niej zawartymi, to powinien liczyć się z reakcją dyrektora szkoły, organu prowadzącego i wojewody. Lamie on konstytucję, która mówi, że wszyscy obywatele maja takie same prawa i obowiązki bez względu na wyznanie i światopoglad, oraz łamie przepisy Karty Nauczyciela - powiedziała minister; za: http:// wpolityce.pl/spoleczenstwo/206998-nauczyciel-ktory-bedzie-uczyl-wg-wiary-katolickiej-zlamie -konstytucje-kluzik-rostkowska-grozi-wychowawcom, (dostęp: 29. 07. 2014).

54 Zob. P. Jaroszyński, Iluminizm, w: Powszechna Encyklopedia Filozofii, t. 4, red. A. Maryniarczyk, Lublin 2003, s. 771-772.

${ }_{55}$ W tym kontekście można z perspektywy religijnej dostrzec, że ateizacja i bezbożnictwo stają się narzędziami i sposobem naśladowania tego, kto od samego początku walczy z Bogiem, tj. diabła. Mogą one także być jakąś formą satanizmu i okrutnego poświęcania samego człowieka psesudobożkom. Miało to miejsce choćby w Kambodży w czasach władzy Czerwonych Khmerów, którzy w budowie „doskonałego” społeczeństwa chłopskiego doprowadzili do eksterminacji około 30\% całej populacji. Były to ofiary składane z ludzi dla czegoś, co postrzegane było jako wyższe od człowieka i od niego ważniejsze, tj. komunizmu; praktyka ucieleśniania nowego porządku społecznego była ludobójcza, eugeniczna i usprawiedliwiana ateizmem.

56 Cyt. za F. Majchrowicz, Historja pedagogiki ze szczególnym uwzględnieniem dziejów wychowania i szkól w Polsce, Warszawa 1922, s. 12-13; zob. także S. Kot, Historia wychowania, t. 1-2, Lwów 1934. 
paidei. Nawet u myślicieli, którzy w swej refleksji filozoficznej nie znajdowali dla religii rzeczowych racji (Arystoteles), istniała troska o zachowanie kultury religijnej oraz związanej z nią formy edukacji i wychowania człowieka ${ }^{57}$. Wiedziano bowiem, że bez religii i jej form wyrazu nie ma w życiu społecznym, państwowym i rodzinnym tak potrzebnej jedności i siły, nie ma ugruntowania zasad moralnych i prawnych; nie ma podstaw do wymagania od człowieka aktów poświęcania się oraz bezinteresownej służby drugim ludziom, nie ma źródła nadziei dla twórczości artystycznej. Słowem zdawano sobie sprawę z tego, że Bóg i religia są zwornikami ludzkiej kultury życia indywidualnego i społecznego i to dzięki nim następuje odkrycie oraz pogłębienie znajomości godności przynależnej ludziom.

Oczywiście, że tak ujęte przeświadczenia miały swe racjonalne uzasadnienie w wielu różnych teoriach filozoficznych, które ukazywały konieczność przyjęcia tezy o istnieniu Absolutu (Boga), gdyż bez istnienia Tegoż, ani nie byłoby możliwe sensowne życie religijne, ani też istnienie całego uniwersum, jakim jest rzeczywistość.

Elementarna znajomość dziedzictwa cywilizacyjnego Zachodu ukazywała to, że problem Boga to nie tylko problem wiary religijnej, lecz sprawa racjonalnego i ostatecznościowego wyjaśnienia całej rzeczywistości, ludzkiej kultury i wszelkich ludzkich poczynań. Negacja Boga w jego istnieniu, a także negacja związku, jaki jest między nim a światem byłaby zatem przyczyną rozstroju całego ładu kulturowego ${ }^{58}$. Rozumiał to już Platon, który w ostatnim swym dziele Prawa przestrzegał przed destrukcyjnym działaniem agitacji ateistycznej i bezbożnictwa ${ }^{59}$. Czy jednak dziś umiemy skorzystać z mądrości starożytnych filozofów i uniknąć zła, które niesie ze sobą ateizacja i bezbożnictwo?

\section{Podsumowanie}

Zachód odkrywając filozofię i jej najwyższą postać, jaką była i jest realistyczna metafizyka, jednocześnie bronił przez szereg wieków przekonania, że cały system ludzkiej edukacji musi być wolny od ateizmu (negacji istnienia Boga), gdyż ten nie tylko jest atakiem na rozum ludzki (zgodą na absurd), ale także atakiem na ludzką kulturę, która ma prowadzić człowieka do pełni jego doskonałości, a to zapewnić może tylko Bóg i zjednoczenie z Nim, jakie dokonuje się za sprawą łaski.

\footnotetext{
57 Znakiem tego jest cała Arystotelesa Polityka, zob. ks. VI-VIII.

58 Zob. H. Romanowski, Filozofia cywilizacji. Prawa realne cywilizacji, jej ideały, typy i pochód, Warszawa 1933-1934.

59 Ważne są tu rozważania Platona zawarte w księdze IX i X w jego Prawach, gdzie przede wszystkim ukazana jest destrukcyjność bezbożnej formy życia dla całego porządku społecznego; zob. także Z. Pańpuch, Rola religii w ludzkiej APETH w tekstach Platona, w: Filozofia o religii. Prace dedykowane Siostrze Profesor Zofii Józefie Zdybickiej, red. W. Dłubacz, Lublin 2009, s. 271-293.
} 
Działanie to łączono także z przekonaniem, że samo życie religijne jest i zawsze pozostanie jednym wielkim manifestem ludzkiej rozumności, wolności i godności. Choć starano się, by miało ono określony religijnie charakter (było chrześcijańskie), nie dokonywano jego zideologizowania i sakralizacji, gdyż sam akt religijny jako indywidualna i dobrowolna działalność człowieka pozostawał jego osobistym i osobowym aktem, do którego można było zawsze zachęcać, lecz nigdy nie było można przymusić, gdyż „wymuszone modlitwy nie są nigdy miłe Bogu”60, a w sumieniu każdy pozostaje wolny.

U podstaw ateistycznej edukacji legła naturalistyczna i w sumie bardzo pesymistyczna wizja człowieka jako istoty biologicznej, pozbawionej godności i autentycznego celu życia, której całe bytowanie wyczerpuje się w biologicznym trwaniu, niczym nie różnym od trwania roślin i zwierząt. Choć naturę człowieka różnie definiowano, czy to jako przedstawiciela rasy (narodowy socjalizm), czy też klasy społecznej (bolszewizm), pozostawał on jednak tylko zwierzęciem, któremu przysługuje chwilowe i bezcelowe trwanie. Ma ono swój kres w rozpadzie materii, po którym nie pozostaje absolutnie nic z samego człowieka. By jednak rozpacz nie zatruła całkowicie ludzkiego ducha, proponowano mu, aby się oddał czy to zajęciom hedonistycznym, czy to ofiarnej pracy dla przyszłych pokoleń, w nadziei, że ich los, choć również skazany na unicestwienie, będzie bardziej znośny i taki, który przeniesie pamięć o tych, co go uczynili mniej przykrym. Propozycje te nie tylko nie mogły posiadać jakiegoś rzeczowego ugruntowania, ale także były w sobie niespójne, pełne przeciwstawieństw i rozbieżności. Toteż ateistyczny i bezbożny paradygmat edukacyjny będzie zawsze starał się zaszczepić w człowieku (mimo pesymistycznych konsekwencji materializmu i naturalizmu) swoistą miłość siebie ponad wszystko, która złączona z samo-adoracją siebie (egotyzmem), subiektywizmem i relatywizmem jest w konsekwencji wrogością wobec wszystkiego, co nie jest mną. Jest wrogością wobec nadziei i dumy, woli walki, sprzeciwu oraz samozadowolenia, które zasadza się na wierności swoim ideałom, wbrew katastrofalnemu biegowi rzeczy ${ }^{61}$. Znane są różne odcienie tegoż egoizmu - klasowe, rasowe, stanowe, kastowe, lecz wszystkie one pozostają jedynie smutną i ograniczoną miłością siebie.

Można z pewnością przypuszczać, że efektem penetracji ludzkiego ducha przez ateizm i bezbożność będzie jednak smutek, bezsilność i ostatecznie nieszczęście

\footnotetext{
60 Zob. zob. Pisma wybrane Pawła Włodkowica, t. 2, Warszawa 1966, s. 39-40.

${ }^{61}$ Można tu przywołać poglądy O. Spenglera, który bardzo mocno wpłynął na duchowość współczesnych i promocję pesymizmu oraz katastrofizmu. Miał on przekonywać, że „Urodziliśmy się w tej epoce i musimy dzielnie iść do końca drogą nam wyznaczoną. Nie pozostaje nam nic innego. Jest naszym obowiązkiem wytrwać na straconej pozycji bez nadziei i bez ratunku. Wytrwać jak ów rzymski żołnierz, którego szkielet znaleziono przed bramą w Pompei, a który zginął, ponieważ podczas wybuchu Wezuwiusza zapomniano odwołać go z posterunku. Oto wielkość, to się nazywa być rasowym. Ten honorowy koniec jest jedyną rzeczą, której nie można ludziom odebrać", O. Spengler, Historia, kultura, polityka. Wybór pism, red. A. Kołakowski, Warszawa 1990, s. 78.
} 
człowieka, bo przecież szczęście ze swej istoty zawsze jest efektem posiadania i rozkoszowania się dobrami, a te w wyniku ateistycznego modelu paidei zostają od człowieka oddzielone i usunięte. Szaleństwo i obłęd hedonistycznej formy życia, utopizm, a nawet sadyzm, tak często związane $\mathrm{z}$ bezbożnictwem i ateizmem, są zawsze i były sposobem „upojenia siebie i zakłamania”, próbą zapomnienia o swej beznadziei.

Na szczęście człowiek jednak rodzi się z rozumem, który, jeśli zostanie udoskonalony prawdą, ma szansę i moc dania odporu fałszowi i błędom, umożliwiając życie dobre i piękne ${ }^{62}$. A jeśli swym sercem otworzy się na Boga, będzie miał także możność życia w świętości, bo nie jest sam i nie żyje tylko dla siebie. Rzecz w tym, by nie nakładał na siebie apriorycznych zasad i koncepcji, które niszczą jego samego. Do takich należy zaliczyć projekty oraz formy ateistycznej, bezbożnej edukacji i wychowania, którym dla dobra człowieka należy dać radykalny odpór.

62 Zob. A. MacIntyre, Dependent Rational Animals. Why Human Beings Need the Virtues, London 1999. 